\title{
Phlebotomines (Diptera: Psychodidae) in forested areas of the Serra da Bodoquena, state of Mato Grosso do Sul, Brazil
}

\section{Eunice AB Galati/ ${ }^{+}$, Vânia LB Nunes*, Paulo C Boggiani**, Maria Elizabeth C Dorval***, Geucira Cristaldo***, Hilda C Rocha***, Elisa T O shiro***, Geraldo A Damasceno-Júnior****}

Departamento de Epidemiologia, Faculdade de Saúde Pública, USP, Av. Dr. Arnaldo 715, 01246-904 São Paulo, SP, Brasil *Centro de Ciências Biológicas, Agrárias e da Saúde, Uniderp, Campo Grande, MS, Brasil **Departamento de Geologia Sedimentar e Ambiental, Instituto de Geociências, Universidade de São Paulo, São Paulo, SP, Brasil ***Departamento de Patologia, Centro de Ciências Biológicas e da Saúde, Universidade Federal de Mato Grosso do Sul, Campo Grande, MS, Brasil ****Departamento de Ciências do Ambiente, Universidade Federal de Mato Grosso do Sul, Campus de Corumbá, Corumbá, MS, Brasil

Investigation was undertaken on the behaviour of the phlebotomine fauna in caves, forests, and anthropic environments of the Serra da Bodoquena, between January 1998 and January 2000. This paper reports on the phlebotomines captured in forested areas with automatic light traps (ALT), Shannon traps (ST), aspiration (AN), at natural resting sites and by human attractiveness (HA) during $24 \mathrm{~h}$. The diversity and abundance of the species were investigated with ALT installed at 16 points (ground level) and 6 in the canopy. Natural infection by flagellates was investigated in females captured with ST, AN, and HA. The sand fly fauna was represented by 23 species. Twenty-two of these were captured with ALT, 15 of them on the western side, and 20 on the eastern. Lutzomyia longipalpis and Nyssomyia whitmani were the most abundant on the former and this species together with Lutzomyia almerioi on the latter side. On the eastern side the ecotopes located close to caves rendered a significantly greater number $(P \leq$ $0.01)$ of specimens than did more distant sites. On this side Lu. almerioi contributed with $56 \%$ of the total number of specimens. Lu. almerioi females were predominantly attracted by humans (96.4\%) and by ST (93.2\%) and three of the 2173 dissected $(0.138 \%)$ presented natural infection by flagellates. The attraction of Lu. almerioi to humans occurred during all seasons, predominantly in the summer, and in nocturnal and diurnal periods. Thus it is bothersome to inhabitants of and visitors to the Bodoquena ridge and a potential vector of flagellates.

Key words: ecology - nictemeral rhythm - human attractiveness - vectors - leishmaniasis - Lutzomyia almerioi

As inhabitants of forested areas, caves, and anthropic environments, the phlebotomines call for special attention, due to the capacity of some species to transmit agents, such as trypanosomatids, bacteria, and viruses, to vertebrates, as well as to cause bother by their painful bites, which may produce allergic manifestations (Forattini 1973, Young \& Duncan 1994).

Among the trypanosomatids transmitted by phlebotomines are the Leishmania, agents of cutaneous and visceral leishmaniases, both of which are spreading throughout Mato Grosso do Sul as also in other Brazilian areas (Nunes et al. 2001).

Information on the presence of phlebotomines in caves on the Serra da Bodoquena (Gnaspini et al. 1994) led the authors to undertake a project to identify the phlebotomine fauna and some aspects of its species behaviour in relation to the human population.

The Bodoquena Plateau, in the state of Mato Grosso do Sul (MS), with many forested areas, numerous caves,

Financial support: Fapesp, process 97/06438-3, Fundação Manuel de Barros/Uniderp

+Corresponding author: egalati@usp.br

Received 16 November 2005

Accepted 2 March 2006 clear rivers, and magnificent carbonate falls (tufas), is an international attraction for ecotourism, one of the important economic activities of the area, which also include cattle-raising, agriculture, and mining.

Several sites on the Serra da Bodoquena, in natural (caves and forests) and anthropic environments, were sampled and followed up between January 1998 and June 2000. Previous records of the serra's phlebotomine fauna captured in 12 caves (Galati et al. 2003a) and in a focus of human cutaneous and canine visceral leishmaniases (Galati et al. 2003b) have already been published.

The aim of this work is to present the relative abundance and diversity of the sand flies captured in various types of natural vegetation on the Serra da Bodoquena, the attractiveness of humans to phlebotomine females, their nictemeral and seasonal activity, and also rates of natural infection by flagellates of females captured by human attractiveness and modified Shannon traps, as well as to assess the potential risk of these insects in transmitting diseases or in causing annoyance to the human population.

\section{MATERIALS AND METHODS}

Study area - The Serra da Bodoquena, situated in the south-central part of the state of Mato Grosso do Sul, forms the extensive carbonate geomorphological watershed separating the basin of the Paraguay river on the west from the sub-basin of the Apa river to the south and that of the Miranda river to the east. 
The Bodoquena plateau is a highland area of which the most prominent feature is the Serra da Bodoquena extending in a N-S direction for $c a .200 \mathrm{~km}$ and from E-W, at its widest point, for $c a .60 \mathrm{~km}$ (Fig. 1). It presents an asymmetrical cross-section with a scarp on the western side and a gentle slope with calcareous residual mountains on the east. The altitude of the plateau varies from 400 to $650 \mathrm{~m}$ (Boggiani \& Coimbra 1995).

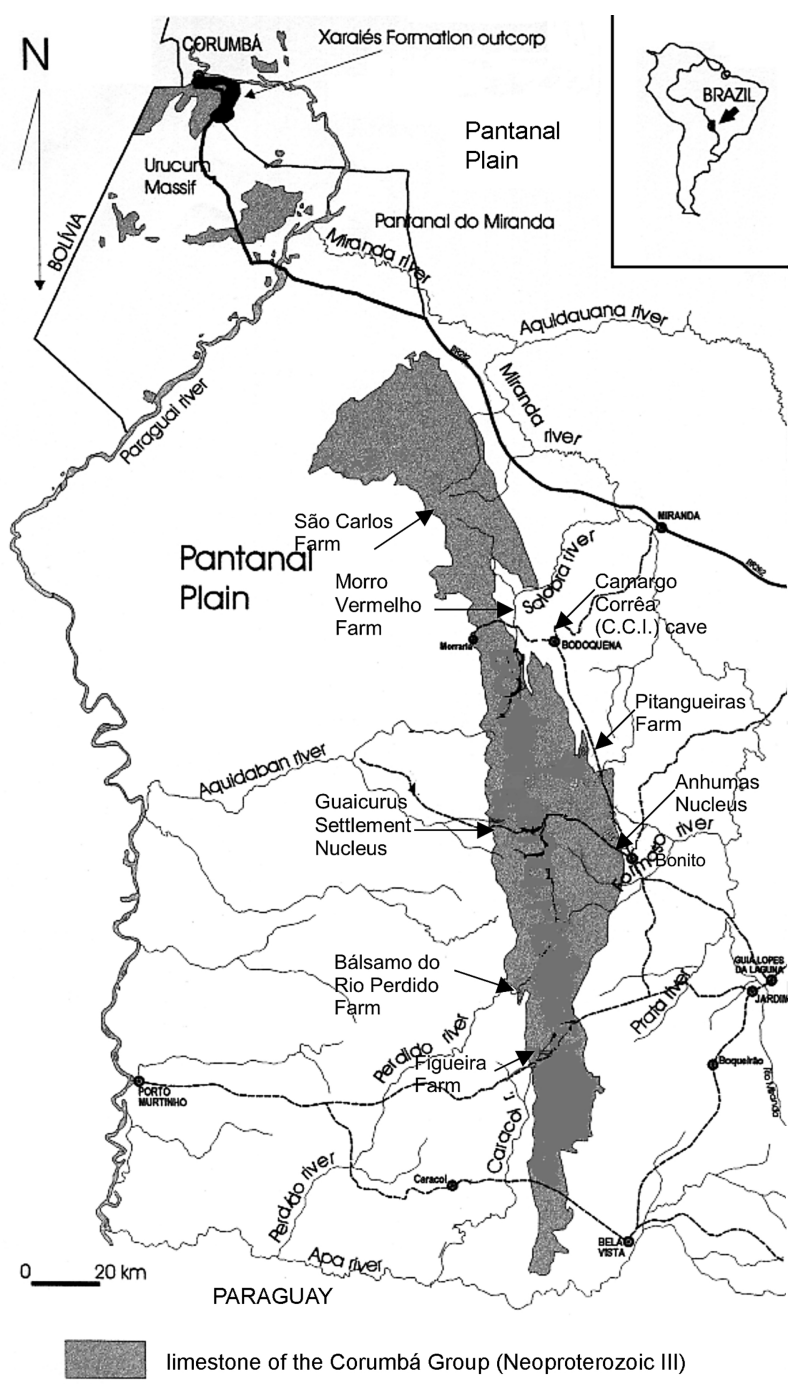

Fig. 1: map of the Serra da Bodoquena. Arrows show the localization of the study areas.

The climate is basically tropical and influenced by polar advections during the winter (June-September) when the environment is drier and the rainfall varies from 30 to 60 $\mathrm{mm} /$ month. The mean annual temperature varies from $20-$ $22^{\circ} \mathrm{C}$ and precipitation from $1300-1700 \mathrm{~mm} /$ year (Alvarenga et al. 1982).

The level areas of the plateau with reddish-yellow Latosol and dark red Latosol are covered with savannah vegetation ("Cerrado") or its variants. In areas with outcrops of carbonate rocks the soil is shallower and covered with seasonal deciduous sub-mountainous forest (Furtado et al. 1982, Veloso et al. 1991).

Near the foothills there generally occurs a dense shrubherbaceous stratum, 1.5-2.0 m high; an intermediate continuous arboreal stratum forming a dossal about $10 \mathrm{~m}$ above the ground with some few trees of $15 \mathrm{~m}$ standing out. Trees 20-25 m high are found in the foothills and bromeliaceae occur either singly or in large clumps on rocks (Furtado et al. 1982).

Many areas surrounding caves may be considered as ecotones between seasonal deciduous sub-mountainous forest and forested savannah or between this latter and low-lying seasonal deciduous forest, making the distinctions between the domains of these types of vegetation unclear (Veloso et al. 1991). An example of an ecotone between the forested savannah and low-lying seasonal deciduous forest may be found surrounding the Lago Azul cave, presenting one of the greatest diversities of the upper Paraguay river. Close to the edge of this ecotone some species typical of forested savannah such as Dipteryx alata are present, merging with vegetation more typical of the forest the closer one approaches the cave. This forest has a dossal of between 12 and $15 \mathrm{~m}$ high. Some taller species reach $20-25 \mathrm{~m}$ and those of the undergrowth 2-8 $\mathrm{m}$. Among the trees with the largest trunk diameter are to be found Combretum leprosum, Eriotheca roseorum, Averrhoidium paraguaiense, Amburana cearensis, Tabebuia roseoalba, Acacia polyphylla, Cedrela fissilis, Aspidosperma subincanum, and Astronium graveolens (Damasceno-Junior, not published).

In a rapid survey of wood plants of the savannah biome in two localities in Bonito county (20 $0^{\circ} 58^{\prime} \mathrm{S} 56^{\circ} 32^{\prime} \mathrm{W}$ and $20^{\circ} 50^{\prime} \mathrm{S} 56^{\circ} 37^{\prime} \mathrm{W}$ ), respective totals of 50 and 57 species were found, while in Bodoquena county (20⒉ $23^{\prime} \mathrm{S} 56^{\circ} 31^{\prime} \mathrm{W}$ ) there were only 28 (Ratter et al. 2001).

The gallery forests present great species variety, distributed according to a well defined structure, with a shrub-herbaceous stratum in which young specimens of arboreal species of between 1 and $2 \mathrm{~m}$ in height are to be found. The taller trees form a canopy of about $15 \mathrm{~m}$ height. Epiphytic plants, bromeliaceae and orchids, grow on the tree trunks, stones and ground near the river banks as also do some small and large leafed ferns, lianas being found everywhere (Furtado et al. 1982). In some areas bamboos are frequent.

\section{Points of capture}

Corumbá county - On the western side of the ridge, on the São Carlos farm (20 08' 42.79" S; 57 $08^{\circ}$ ' 37.44" $\mathrm{W})$. Three areas: two in a seasonal deciduous sub-mountainous forest (ground level) and the other in a forested savannah/seasonal deciduous sub-mountainous forest ecotone (ground level).

Bodoquena county - On the eastern side of the ridge. Two areas: 1) in a well-preserved seasonal deciduous submountainous forest (ground level) situated on Morro Vermelho farm ( $\left.20^{\circ} 26^{\prime} \mathrm{S} ; 56^{\circ} 43^{\prime} \mathrm{W}\right)$, close to the Estreito da Serra cave (20 $26^{\prime} 18.33213$ ' S; 56 $42^{\prime} 40.51587$ ' W); 2 ) in a degraded seasonal deciduous sub-mountainous for- 
est (ground level) situated in the urban area of Bodoquena close to the Camargo Corrêa Industrial (C.C.I.) cave (20³3'17.99897'’S; 5640'49.21034”W).

Bonito county - Three localities: Guaicurus Settlement nucleus (on the western side); Pitangueiras farm; and Anhumas nucleus (both on the eastern side).

Guaicurus Settlement nucleus: three areas were sampled: Três Coxilhas farm situated to the north of the Guaicurus Settlement, in an area covered with relatively well-preserved ecotone: forested savannah/seasonal deciduous sub-mountainous forest, with the emergent trees being of 20-25 $\mathrm{m}$ in height. Two points, both situated $\mathrm{ca}$. $100 \mathrm{~m}$ from Gaúcho's cave (2052'19.28924' $\mathrm{S}$; $56^{\circ} 50^{\prime} 46.24762$ '” $\mathrm{W}$ ), as it is known locally were sampled: canopy and ground. Guaicurus Settlement: two areas: Small farm 121 (ground level) and Small farm 123 (ground level), about $200 \mathrm{~m}$ from each other, both representing seasonal deciduous sub-mountainous forest, now considerably modified, belonging to two private dwellings; the former close to Cezário's cave (2052' 19.28924" S; $56^{\circ} 50^{\prime} 45.24762$ ' W) and both located ca. $1 \mathrm{~km}$ from Gaúcho's cave. Salobrão farm located on the northeastern edge of the Guaicurus Settlement (about $10 \mathrm{~km}$ from the small farms 121 and 123). Two forests were sampled: seasonal deciduous sub-mountainous forest (ground level), $c a .100 \mathrm{~m}$ from a domicile and gallery forest (ground level) in which bamboos are abundant, $c a .150 \mathrm{~m}$ from this domicile.

The Pitangueiras farm is situated half-way between Bodoquena and Bonito. Two forests (about $200 \mathrm{~m}$ from each other) and delimited by pasture were sampled: a relatively well preserved ecotone between forested savannah/seasonal deciduous sub-mountainous forest close to the Pitangueiras cave $\left(20^{\circ} 52^{\prime} 10.34308^{\prime}\right.$ ' $S$; 56 35'06. $\left.25137^{\prime \prime} \mathrm{W}\right)$ : canopy and ground level and a gallery forest: canopy and ground level.

Anhumas nucleus: three ecotone areas: forested savannah/low-lying seasonal deciduous forest with emergent trees of 20-25 m in height were sampled: canopy, on São Miguel farm close to the São Miguel cave (21ํ6'28.52753'S; 56³4'43.15047' W); ground level, surrounding the Lago Azul cave ( $21^{\circ} 08^{\prime} 40.46471^{\prime}$ 'S; $\left.56^{\circ} 35^{\prime} 25.90941^{\prime \prime} \mathrm{W}\right), c a .13 \mathrm{~km}$ from the São Miguel cave; canopy and ground level, on the Anhumas farm, about $500 \mathrm{~m}$ from the Lago Azul cave.

Jardim county - On the western side of the ridge. Two localities were sampled: Bálsamo do Rio Perdido farm ( $\left.21^{\circ} 25^{\prime} 00^{\prime \prime} \mathrm{S} ; 5^{\circ} 45^{\prime} 00^{\prime \prime} \mathrm{W}\right)$ located close to the Perdido river, on the border with Porto Murtinho county, where two forests were searched: seasonal deciduous sub-mountainous forest (ground level), $c a .80 \mathrm{~m}$ from a domicile and $50 \mathrm{~m}$ from a cattle pen and gallery forest (canopy) ca. $60 \mathrm{~m}$ from the domicile and Figueira farm, in two areas: a seasonal deciduous sub-mountainous forest (ground level) close to a cavity called Buraco das Abelhas (21³1'20.61054'S; 5642'37.16254'W); 2.2) in an ecotone between forested savannah and seasonal deciduous submountainous forest close to Buraco da Sucuri (21³1'20.61054'’S; 5642’37.16254”W).
Methodology - The captures of sand flies were carried out, independently of the official summertime in force during part of the period, using four techniques: automatic light traps (Natal et al. 1991), aspiration, modified white and black Shannon traps (Galati et al. 2001), and human attractiveness.

Captures with automatic light traps installed in the canopy (ca. $10 \mathrm{~m}$ above the ground level) and $1 \mathrm{~m}$ above the ground level, were undertaken fortnightly by local inhabitants from 6:00 p. m. to 6:00 a. m.

The capture periods were not the same for all areas: Bonito county: Pitangueiras farm - January 1998 to January 2000; Anhumas farm, São Miguel farm; Lago Azul; Três Coxilhas farm and small farm 121 - January 1998 to December 1999; small farm 123 - April 1998 to December 1999; Salobrão farm - June 1998 to December 1999; Jardim county: Bálsamo do Rio Perdido farm - January to December 1998; Figueira farm - February 1999 to January 2000; Corumbá county: São Carlos farm - February 1999 to January 2000 .

Apart from these captures three others, in February, May, and July 1998 were undertaken close to the Estreito da Serra cave in Bodoquena county.

For the purpose of collecting phlebotomines for dissection and to observe natural infection by flagellates, captures were undertaken by aspiration at the insects' probable natural resting sites and with modified Shannon traps.

Aspiration of sand flies in their natural resting sites (tree trunks, exposed roots, fallen leaves under and between the rocks and armadillo burrows) was undertaken with an aspirator (6 volts) during the afternoon by members of the team without regular periodicity, to a total of $102.5 \mathrm{~h}$, as follows: Bodoquena county - in forested areas surrounding C.C.I. cave (14.5 h); Três Coxilhas farm - in forested areas surrounding Gaucho's cave (6 h); Guaicurus Settlement - in the seasonal deciduous sub-mountainous forest of the small farms $121(24 \mathrm{~h})$ and $123(15 \mathrm{~h})$; Pitangueiras farm - in forested areas surrounding Pitangueiras cave (3 h); Anhumas nucleus - in forested areas surrounding Lago Azul cave (14 h) and São Miguel cave $(9 \mathrm{~h})$ and Bálsamo do Rio Perdido farm - seasonal deciduous sub-mountainous forest $(13 \mathrm{~h})$ and the gallery forest (4 h).

Captures with modified Shannon traps were undertaken between 6:00 p.m. and 10:00 p.m. by two members of the team in each season of the year at some points on the Serra da Bodoquena. During 1998, the captures were carried out in the gallery forest of the Bálsamo do Rio Perdido farm and in 1998-1999 in front of the caves Pitangueiras, Lago Azul, and São Miguel caves.

The females captured were dissected for the investigation of natural infection by flagellates as described by Galati et al. (2003a). When natural infection by flagellates was observed, the liquid containing the digestive tract was aspirated from the slide and inoculated into the hind legs of a hamster and also into NNN (Neal, Novy, and Nicole) medium with the liquid phase consisting of BHI (bovine brain, heart infusion) plus penicillin $1000 \mathrm{IU} / \mathrm{ml}$ 
and streptomycin sulfate $100 \mu \mathrm{g} / \mathrm{ml}$. The residual part of the slide and the cover-glass were fixed with acetone and sent to the Instituto Evandro Chagas, Belém, state of Pará for the identification of the flagellates, using monoclonal antibodies.

Captures by human attractiveness were undertaken, once in each season, for the purpose of observing the nictemeral rhythm and also investigating the natural infection by flagellates, in two localities: in front of the Pitangueiras cave mouth, Bonito county 1/2.VI.1998, 28/ 29.VII.1998, 28/29.X.1998 and 2/3.II.1999, and of the C.C.I. cave, in Bodoquena town on 24/25.III.1999, 30.VI/ 1.VII.1999, 22/23.IX.1999 and 27/28.XII.1999. The captures began about midday and were carried out continuously for $24 \mathrm{~h}$. Two members of the staff stayed at the capture site, but only one of the team had her face, hands and the lower part of the legs exposed. The person who was the attraction undertook the captures on herself, but when the number of insects attracted was large, the other person of the pair helped her, so as to guarantee the capture of all the females.

All the specimens captured with automatic light traps and those captured with the other techniques, excepting the females dissected, were identified after their clarification in accordance with the method described by Forattini (1973) and examined in creosote. Some of these specimens were mounted on slides and deposited in the collection of the Departamento de Epidemiologia of the Faculdade de Saúde Pública, USP.

The pluviometric data for Bonito county from 1981 to 1999 were obtained from the Agricultural Cooperative of Bonito county and those on temperature and relative humidity by the use of a thermo-hygrometer (Presto ${ }^{\circledR}$ ).

Statistical analysis - The frequency of capture by site was obtained by Williams' geometric mean (Haddow 1960).

For the abundance calculation, the data used were those of the captures carried out during at least one year, between January 1998 and January 2000.

The standardised index of species abundance (SISA) was calculated in accordance with Roberts and Hsi (1979).

The $\chi^{2}$ test $(\mathrm{N} \geq 10)$ or binomial test $(5 \leq \mathrm{N} \leq 9)$ was used for the comparison between the number of insects captured during the same period at two different sites, as also between the number of females captured on humans at different seasons.

The estimates of diversity were obtained using Shannon's index $(\mathrm{H})$ and that for evenness Pielou's index (J) (Hayek \& Buzas 1997). The species nomenclature follows Galati (2003).

\section{RESULTS}

With the four methods of capture used, a total of 5137 sand flies, belonging to 23 species, were captured: $B i$ chromomyia flaviscutellata, Brumptomyia avellari, Brumptomyia brumpti, Brumptomyia cunhai, Evandromyia corumbaensis, Evandromyia lenti, Evandromyia sallesi, Evandromyia teratodes, Evandromyia termitophila, Lutzomyia almerioi, Lutzomyia longipalpis, Martinsmyia oliveirai,
Micropygomyia acanthopharynx, Micropygomyia peresi, Micropygomyia quinquefer, Migonemyia bursiformis, Nyssomyia whitmani, Pintomyia kuscheli, Psathyromyia aragaoi, Psathyromyia campograndensis, Psathyromyia punctigeniculata, Psathyromyia shannoni, and Sciopemyia sordellii.

Twenty-two species and 1822 phlebotomines (43.1\% males and $56.9 \%$ females) were captured in the 22 ecotopes (13 on the western and 9 on the eastern sides) sampled with automatic light traps ( $\mathrm{N}$ total $=761$ ), giving an average of only 2.4 phlebotomines per trap; 1.3 on the western and 3.8 on the eastern sides (Tables I, III).

The fauna of the western side consisted of 15 species, three of them Bi.flaviscutellata, E. teratodes, and E. lenti, being captured only on the São Carlos farm and Br. avellari on the Bálsamo do Rio Perdido farm. Lu. almerioi, the most frequent species on the Serra da Bodoquena, was not captured at either the most northerly or the most southerly localities, in the Corumbá and Jardim counties, respectively. In 4 of the ecotopes, only 1 or 2 species were captured; and in the others, the number of species varied from 5 to 8, with the ecotone of the São Carlos farm presenting the highest diversity $(\mathrm{H}=1.94)$ and the second highest evenness $(J=0.93)$ indexes; the inverse $(H=1.85$; $\mathrm{J}=0.95$ ) occurred on the small farm 123 . The lowest indexes occurred in the seasonal deciduous sub-mountainous forest of the Bálsamo do Rio Perdido farm (Table I).

On the eastern side the fauna consisted of 20 species. Br. cunhai, E. sallesi, and Mi. acanthopharynx were captured only on the Pitangueiras farm and Pi. kuscheli at Lago Azul. With the exception of the ecotope in Bodoquena county in which a few captures were made, the number of species varied from 6 to 15; the two highest diversity and evenness indexes occurred on the ground level of the gallery forest of Pitangueiras $(\mathrm{H}=1.96 ; \mathrm{J}=$ $0.85)$ and in the ecotone of the Anhumas $(\mathrm{H}=1.91 ; \mathrm{J}=$ 0.92 ) farms. The lowest diversity and evenness indexes (S $=1.29 ; \mathrm{J}=0.48$ ) were obtained on the ground level of the ecotone on Pitangueiras farm (Table III).

Of the 22 species captured with automatic light traps, 10 contributed with $95.4 \%$ of the specimens: Lu. almerioi (42.2\%), N. whitmani (18.7\%), Lu. longipalpis (12.7\%), E. corumbaensis (5.4\%), Ma. oliveirai (4.8\%), Mi. quinquefer (4.3\%), Ps. shannoni (3\%), S. sordellii (1.8\%), Mi. peresi (1.3\%), and Pi. kuscheli (1.2\%). On the western and eastern sides the respective contributions of these species were: Lu. almerioi $(10.5 ; 55.6 \%), N$. whitmani (40.5; 9.5\%), Lu. longipalpis $(13.4 ; 12.4 \%)$, E. corumbaensis $(9.8 ; 3.5 \%)$, Ma. oliveirai (4.6; 4.9\%), Mi. quinquefer $(0 ; 6.1 \%)$, Ps. shannoni $(7.2 ; 1.3 \%)$, S. sordellii (4.1; 0.8\%), Mi. peresi $(0 ; 1.9 \%)$, and Pi. kuscheli (3.9; $0.08 \%$ ). So, only Lu. longipalpis and Ma. oliveirai had similar frequencies on both sides (Tables I, III).

The frequencies of phlebotomines obtained by Williams' average are presented by locality for the western side in Table II and those for the eastern side in Table IV.

The average per capture on the eastern side was 2.4 times higher than that on the western side. On this latter side, the seasonal deciduous sub-mountainous forest of Bálsamo do Rio Perdido farm presented the highest value and the two extreme points of the ridge that were sampled, Corumbá and Jardim counties, the lowest. 


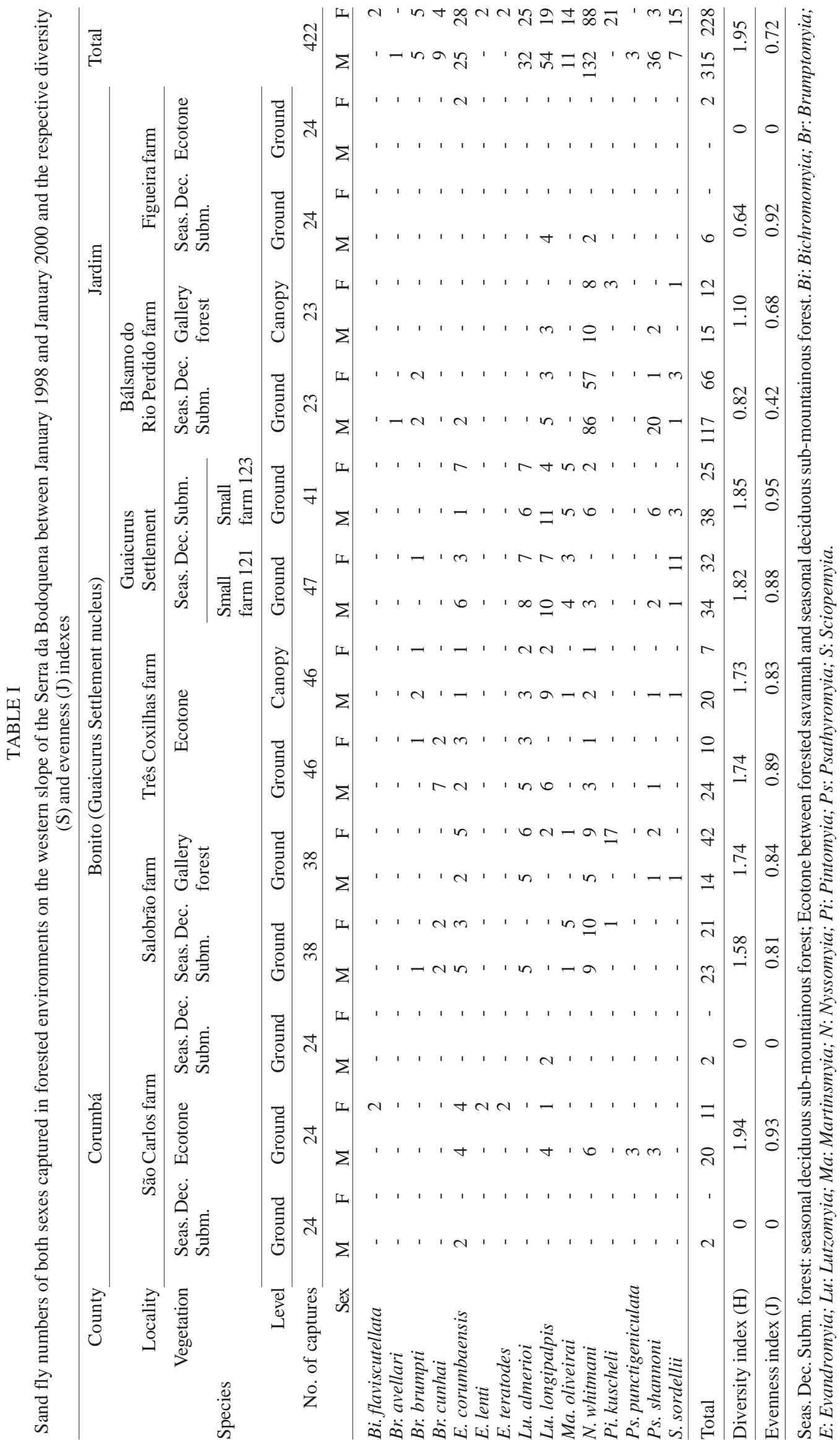




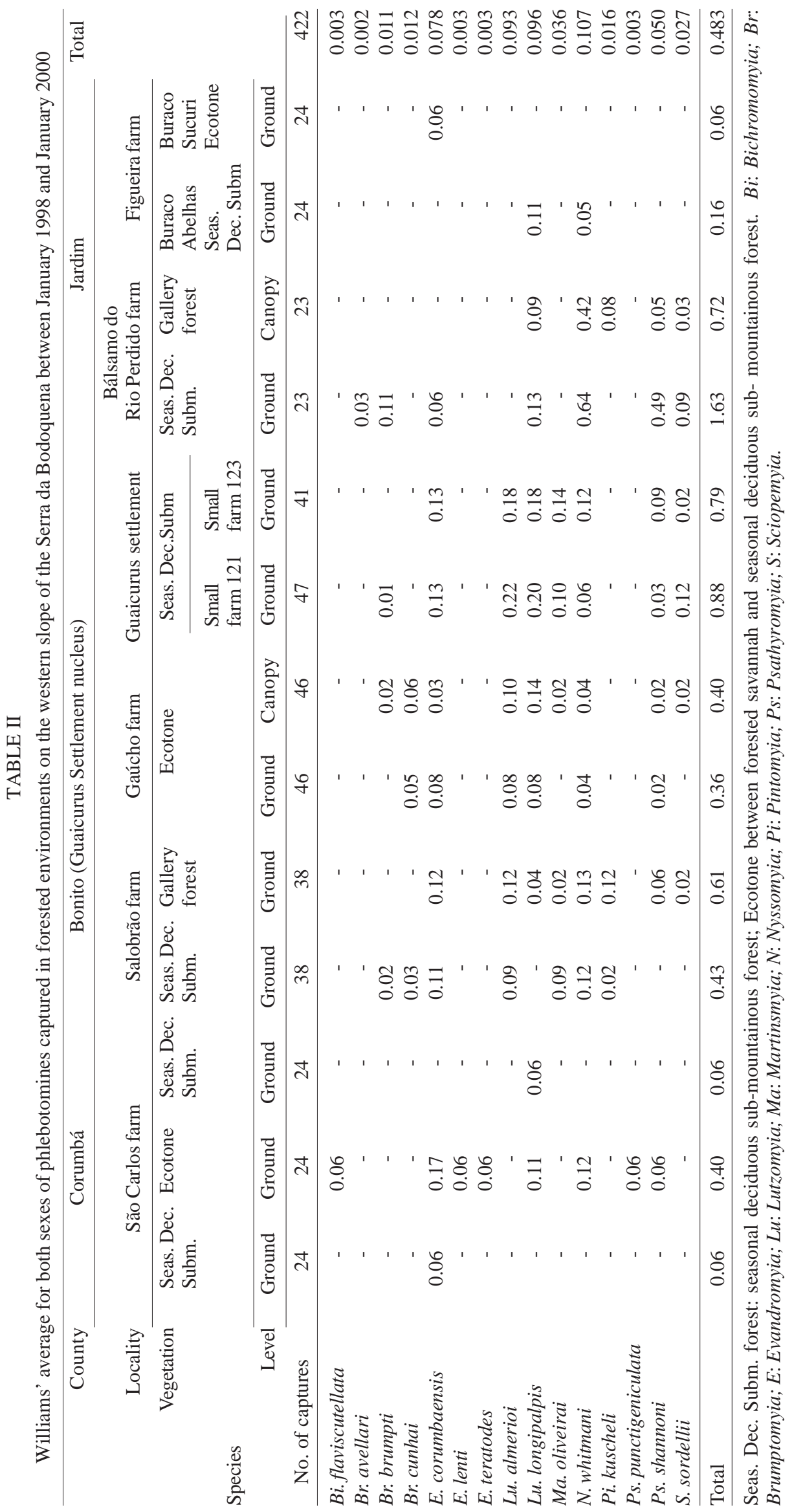




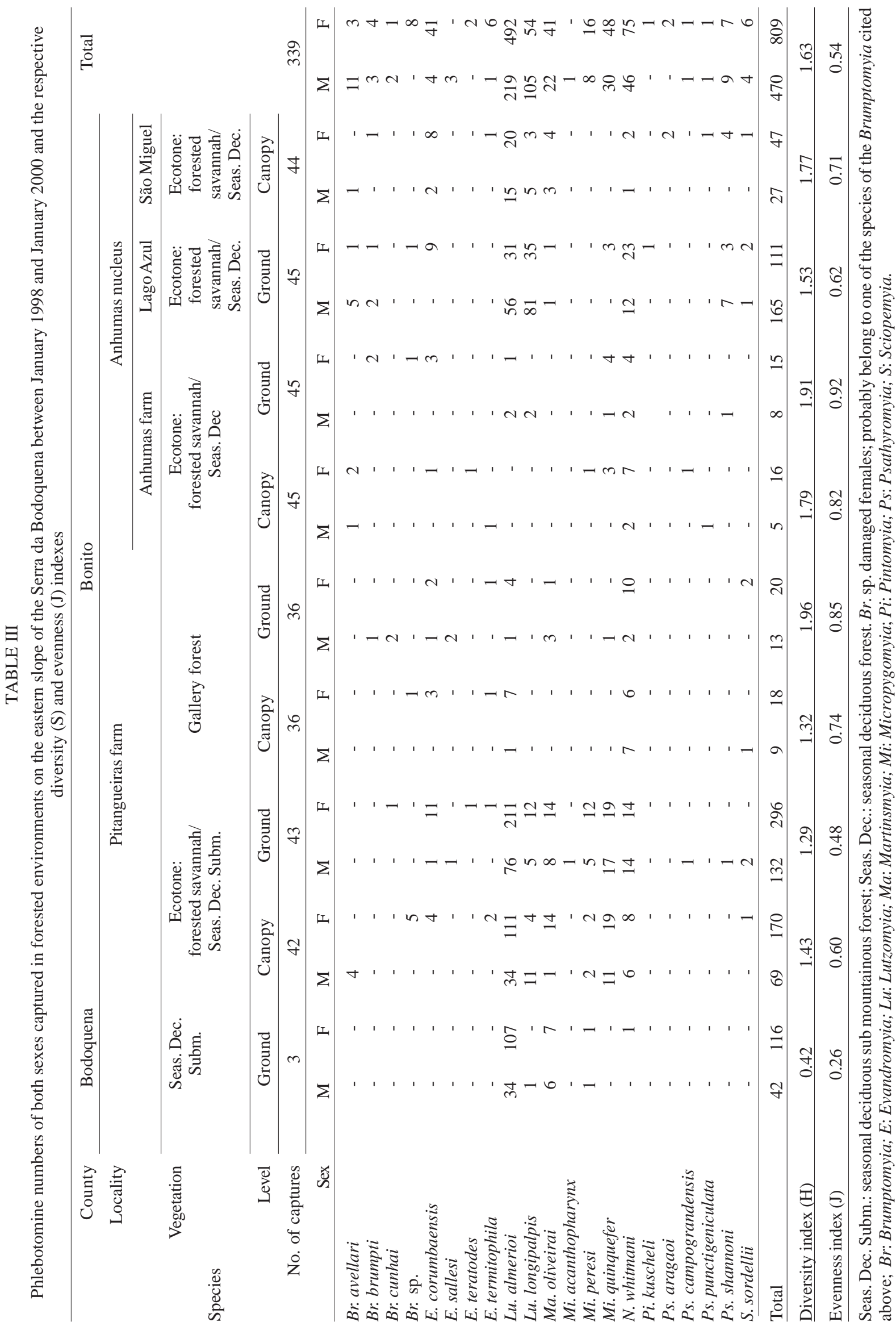


The comparison between the total sand flies captured at a particular point in relation to that of each of the others during a simultaneous period for the western and eastern sides is given in Tables V and VI, respectively. The two points with the greatest respective numbers of phlebotomines captured during simultaneous periods on the western and eastern sides were in the seasonal deciduous sub-mountainous forest on the Bálsamo do Rio Perdido farm $(\mathrm{N}=182)$ and the ecotone of the Pitangueiras farm $(\mathrm{N}=238)$, showing a statistically significant difference $(\mathrm{P}<0.01)$ between them.

The SISA for each side separately and for both together are presented in Table VII. Of the 22 species captured with automatic light traps, only six are included as more abundant, at least on one of the sides. None of them was among the most abundant on both sides. When all the ecotopes were taken together, $N$. whitmani came first in the ranking.

The seasonal distribution of the phlebotomines (all species) at those points with captures in all the seasons of 1998 and 1999, on the western (Guaicurus nucleus) and eastern (Pitangueiras farm and Anhumas nucleus) sides is shown in Fig. 2.

The highest total frequencies, considering all the species captured over the two years, were observed in the summer, on both the western and eastern sides, the highest values occurring on this latter.

The monthly rain distribution in Bonito county, from June 1997 to December 1999, and of the monthly average of the 1981-1999 period is presented in Fig. 3. During seven months of 1998, the rains exceeded the average for the period from 1981-1999, but in 1999 the rains occurred practically only during the summer.

Twelve specimens belonging to five species of sand fly were captured by aspiration in the forests. The distribution of species according to resting site, number of specimens, sex and females dissected (d) is: Bálsamo do Rio Perdido farm, under rocks and in their fissures in sea-

TABLE IV

Williams' average of both sexes of the phlebotomines captured in forested environments on the eastern slope of the Serra da Bodoquena between January 1998 and January 2000

\begin{tabular}{|c|c|c|c|c|c|c|c|c|c|c|}
\hline County & Bodoquena & & & & Bonito & & & & & Total \\
\hline Locality & & & Pitangue & ras farm & & & Anhuma & is nucleus & & \\
\hline & & & & & & Fazenda & Anhumas & Lago Azul & S. Miguel & \\
\hline Vegetation & $\begin{array}{l}\text { Seas. Dec. } \\
\text { Subm. }\end{array}$ & $\begin{array}{r}\text { Eco } \\
\text { forested } \\
\text { Seas. D }\end{array}$ & $\begin{array}{l}\text { one: } \\
\text { avannah/ } \\
\text { ec. Sub. }\end{array}$ & Galler & forest & $\begin{array}{r}\text { Eco } \\
\text { forested } \\
\text { Seas }\end{array}$ & $\begin{array}{l}\text { one: } \\
\text { avannah/ } \\
\text { Dec. }\end{array}$ & $\begin{array}{c}\text { Ecotone: } \\
\text { forested } \\
\text { savannah/ } \\
\text { Seas. Dec. }\end{array}$ & $\begin{array}{c}\text { Ecotone: } \\
\text { forested } \\
\text { savannah/ } \\
\text { Seas. Dec. }\end{array}$ & \\
\hline Level & Ground & Canopy & Ground & Canopy & Ground & Canopy & Ground & Ground & Canopy & \\
\hline N. of captures & 3 & 42 & 43 & 36 & 36 & 45 & 45 & 45 & 44 & 339 \\
\hline Br. avellari & - & 0.04 & - & - & - & 0.04 & - & 0.08 & 0.02 & 0.027 \\
\hline Br. brumpti & - & - & - & - & 0.02 & - & 0.03 & 0.05 & 0.02 & 0.014 \\
\hline Br. cunhai & - & - & 0.02 & - & 0.04 & - & - & - & - & 0.006 \\
\hline$B r$. sp. & - & 0.04 & - & 0.02 & - & - & 0.02 & 0.02 & - & 0.012 \\
\hline E. corumbaensis & - & 0.07 & 0.17 & 0.03 & 0.06 & 0.02 & 0.05 & 0.10 & 0.13 & 0.078 \\
\hline E. sallesi & - & - & 0.02 & - & 0.04 & - & - & - & - & 0.006 \\
\hline E. teratodes & - & - & 0.02 & - & - & 0.02 & - & - & - & 0.004 \\
\hline E. termitophila & - & 0.03 & 0.02 & 0.02 & 0.02 & 0.02 & - & - & 0.02 & 0.014 \\
\hline Lu. almerioi & 16.02 & 1.55 & 1.82 & 0.09 & 0.08 & - & 0.05 & 0.47 & 0.36 & 0.472 \\
\hline Lu. longipalpis & 0.26 & 0.22 & 0.15 & - & - & - & 0.03 & 0.31 & 0.12 & 0.101 \\
\hline Ma. oliveirai & 2.78 & 0.20 & 0.32 & - & 0.07 & - & - & 0.03 & 0.09 & 0.040 \\
\hline Mi. acanthopharynx & - & - & 0.02 & - & - & - & - & - & - & 0.002 \\
\hline Mi.peresi & 0.59 & 0.07 & 0.19 & - & - & 0.02 & - & - & - & 0.038 \\
\hline Mi. quinquefer & - & 0.42 & 0.46 & - & 0.02 & 0.05 & 0.06 & 0.03 & - & 0.117 \\
\hline N. whitmani & 0.26 & 0.22 & 0.28 & 0.18 & 0.18 & 0.12 & 0.10 & 0.26 & 0.04 & 0.170 \\
\hline Pi. kuscheli & - & - & - & - & - & - & - & 0.02 & - & 0.002 \\
\hline Ps. aragaoi & - & - & - & - & - & - & - & - & 0.03 & 0.004 \\
\hline Ps. campograndensis & - & - & 0.02 & - & - & 0.02 & - & - & - & 0.004 \\
\hline Ps. punctigeniculata & - & - & - & - & - & 0.02 & - & - & 0.02 & 0.004 \\
\hline Ps. shannoni & - & - & 0.02 & - & - & - & 0.02 & 0.11 & 0.07 & 0.027 \\
\hline S. sordellii & - & 0.02 & 0.03 & 0.02 & 0.04 & - & - & 0.05 & 0.02 & 0.021 \\
\hline Total & 25.23 & 2.98 & 4.18 & 0.37 & 0.54 & 0.30 & 0.33 & 1.50 & 0.93 & 1.154 \\
\hline
\end{tabular}

Seas. Dec. Subm.: seasonal deciduous sub-mountainous forest; Seas. Dec.: seasonal deciduous forest; $B r$. sp. damaged females; probably belong to one of the species of Brumptomyia cited above. Br. sp. damaged females; probably belong to one of the species of the Brumptomyia cited above; Br: Brumptomyia; E: Evandromyia; Lu: Lutzomyia; Ma: Martinsmyia; Mi: Micropygomyia; Pi: Pintomyia; Ps: Psathyromyia; S: Sciopemyia. 


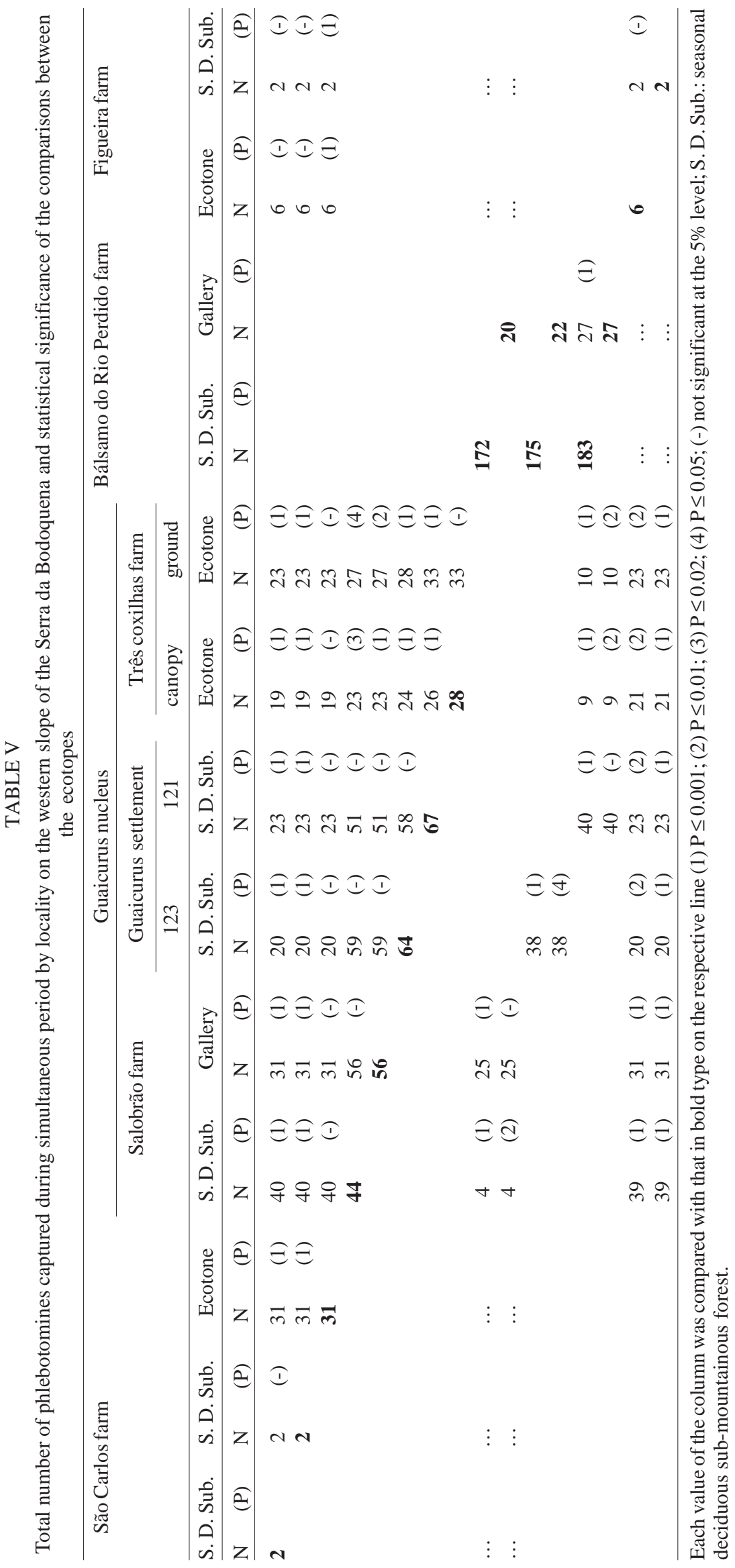


sonal deciduous sub-mountainous forest - Brumptomyia sp. 1 female (d), E. corumbaensis 1 male, Lu. almerioi 1 female (d), and Lu. longipalpis 1 male; Guaicurus Settlement: small farm 121, tree trunks - Lu. longipalpis 2 males; small farm 123, under rocks and in their fissures - $L u$. longipalpis 2 males; Pitangueiras farm, around the cave mouth (tree trunks and exposed roots) - Lu. almerioi 2 females (2 d) and Anhumas nucleus, around the São Miguel cave (under rocks and in their fissures) - $L u$. almerioi 1 female and $M g$. bursiformis 1 male. Three females of Lu. almerioi and one of $\mathrm{Br}$. sp. were dissected and gave negative results for infection by flagellates.

A total of 2109 specimens, $84.02 \%$ of them females and representing fifteen species, were captured in Shannon traps (Table VIII). Of this total, $L u$. almerioi predominated absolutely with $82.2 \%$ of all males and $93.2 \%$ of all females. Of the females dissected, Lu. almerioi contributed $92.6 \%$. Of a total of 901 females dissected from the

\section{TABLE VI}

Total number of phlebotomines captured during simultaneous period by locality on the eastern slope of the Serra da Bodoquena and statistical significance of the comparisons between the ecotopes

\begin{tabular}{|c|c|c|c|c|c|c|c|c|c|c|c|c|c|c|c|}
\hline \multirow{2}{*}{\multicolumn{8}{|c|}{ Pitangueiras farm }} & \multicolumn{8}{|c|}{ Anhumas Nucleus } \\
\hline & & & & & & & & \multicolumn{4}{|c|}{ Anhumas farm } & \multicolumn{2}{|c|}{ Lago Azul } & \multicolumn{2}{|c|}{$\begin{array}{l}\text { S. Miguel } \\
\text { farm }\end{array}$} \\
\hline \multicolumn{4}{|c|}{ Ecotone } & \multicolumn{4}{|c|}{ Gallery forest } & \multicolumn{4}{|c|}{ Ecotone } & \multirow{2}{*}{\multicolumn{2}{|c|}{$\begin{array}{l}\text { Ecotone } \\
\text { Ground }\end{array}$}} & \multirow{2}{*}{\multicolumn{2}{|c|}{$\begin{array}{l}\text { Ecotone } \\
\text { Canopy }\end{array}$}} \\
\hline \multicolumn{2}{|c|}{ Canopy } & \multicolumn{2}{|c|}{ Ground } & \multicolumn{2}{|c|}{ Canopy } & \multicolumn{2}{|c|}{ Ground } & \multicolumn{2}{|c|}{ Canopy } & \multicolumn{2}{|c|}{ Ground } & & & & \\
\hline $\mathrm{N}$ & (P) & $\mathrm{N}$ & $(\mathrm{P})$ & $\mathrm{N}$ & (P) & $\mathrm{N}$ & (P) & $\mathrm{N}$ & (P) & $\mathrm{N}$ & (P) & $\mathrm{N}$ & (P) & $\mathrm{N}$ & $(\mathrm{P})$ \\
\hline \multirow[t]{2}{*}{239} & & 428 & (1) & & & & & 20 & (1) & 22 & (1) & 229 & $(-)$ & 71 & (1) \\
\hline & & 428 & & & & & & 20 & (1) & 22 & (1) & 229 & (1) & 71 & (1) \\
\hline 159 & (1) & 333 & (1) & 8 & & 6 & $(-)$ & 16 & $(-)$ & 20 & (4) & 214 & (1) & 42 & (1) \\
\hline \multirow[t]{4}{*}{159} & (1) & 333 & (1) & 8 & $(-)$ & 6 & & 16 & (4) & 20 & (2) & 214 & (1) & 42 & (1) \\
\hline & & & (1) & 8 & (3) & 6 & (2) & 21 & & 22 & $(-)$ & 276 & (1) & 74 & (1) \\
\hline & & & (1) & 8 & (1) & 6 & (2) & 21 & $(-)$ & 22 & & 276 & (1) & 74 & (1) \\
\hline & & & & & & & & & & & & 276 & & 74 & (1) \\
\hline
\end{tabular}

Each value of the column was compared with that in bold type on the respective line (1) $\mathrm{P} \leq 0.001$; (2) $\mathrm{P} \leq 0.01$; (3) $\mathrm{P} \leq 0.02$; (4) $\mathrm{P}$ $\leq 0.05$; (-) not significant at the $5 \%$ level.

TABLE VII

Standardised index of species abundance (SISA) for phlebotomines captured with automatic light traps in forested areas of the Serra da Bodoquena, over at least one year, in the period from January 1998 to January 2000

\begin{tabular}{|c|c|c|c|c|c|c|}
\hline \multirow[t]{2}{*}{ Species } & \multicolumn{2}{|c|}{ Overall } & \multicolumn{2}{|c|}{ Western side } & \multicolumn{2}{|c|}{ Eastern side } \\
\hline & SISA & Position & SISA & Position & SISA & Position \\
\hline Bi.flaviscutellata & 0.024 & 19th & 0.019 & 13 th & - & - \\
\hline Br. avellari & 0.127 & 11th & 0.019 & 13 th & 0.271 & 9 th \\
\hline Br. brumpti & 0.192 & 9 th & 0.130 & 9 th & 0.214 & 11 th \\
\hline Br. cunhai & 0.111 & 12 th & 0.125 & 10 th & 0.083 & 13 th \\
\hline E. corumbaensis & 0.657 & 2nd & 0.563 & $3 r d$ & 0.698 & $3 r d$ \\
\hline E. lenti & 0.048 & 16 th & 0.125 & 10th & - & - \\
\hline E. sallesi & 0.032 & 17 th & - & - & 0.083 & 13 th \\
\hline E.teratodes & 0.054 & 15 th & 0.105 & 11 th & 0.078 & 14 th \\
\hline E. termitophila & 0.159 & 10 th & - & - & 0.292 & 8 th \\
\hline Lu. almerioi & 0.561 & 4 th & 0.375 & 4 th & 0.818 & 2nd \\
\hline Lu. longipalpis & 0.607 & $3 \mathrm{rd}$ & 0.649 & $1 \mathrm{st}$ & 0.474 & 5 th \\
\hline Ma. oliveirai & 0.323 & 6 th & 0.188 & 7 th & 0.438 & 6 th \\
\hline Mi. acanthopharynx & 0.004 & 20th & - & - & 0.010 & 17 th \\
\hline Mi.peresi & 0.077 & 13 th & - & - & 0.203 & 12 th \\
\hline Mi. quinquefer & 0.208 & 8 th & - & - & 0.547 & 4 th \\
\hline N. whitmani & 0.736 & $1 \mathrm{st}$ & 0.596 & 2nd & 0.870 & $1 \mathrm{st}$ \\
\hline Pi. kuscheli & 0.127 & 11 th & 0.164 & 8 th & 0.031 & 16 th \\
\hline Ps. aragaoi & 0.024 & 19th & - & - & 0.062 & 15 th \\
\hline Ps. campograndensis & 0.030 & 18 th & - & - & 0.078 & 14 th \\
\hline Ps. punctigeniculata & 0.071 & 14th & 0.043 & 12 th & 0.099 & 12 th \\
\hline Ps. shannoni & 0.341 & 5 th & 0.288 & 5 th & 0.250 & 10th \\
\hline S. sordellii & 0.302 & 7th & 0.197 & 6 th & 0.328 & 7 th \\
\hline
\end{tabular}

Br: Brumptomyia; E: Evandromyia; Lu: Lutzomyia; Ma: Martinsmyia; Mi: Micropygomyia; Pi: Pintomyia; Ps: Psathyromyia; S: Sciopemyia. 


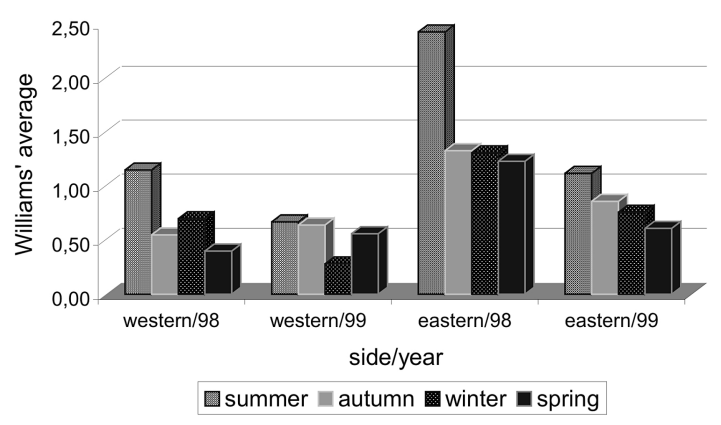

Fig. 2: seasonal distribution of the phlebotomines (all species) at those points with captures in all seasons of 1998 and 1999, on the western (Guaicurus nucleus) and eastern (Pitangueiras farm and Anhumas nucleus) sides of the Serra da Bodoquena.

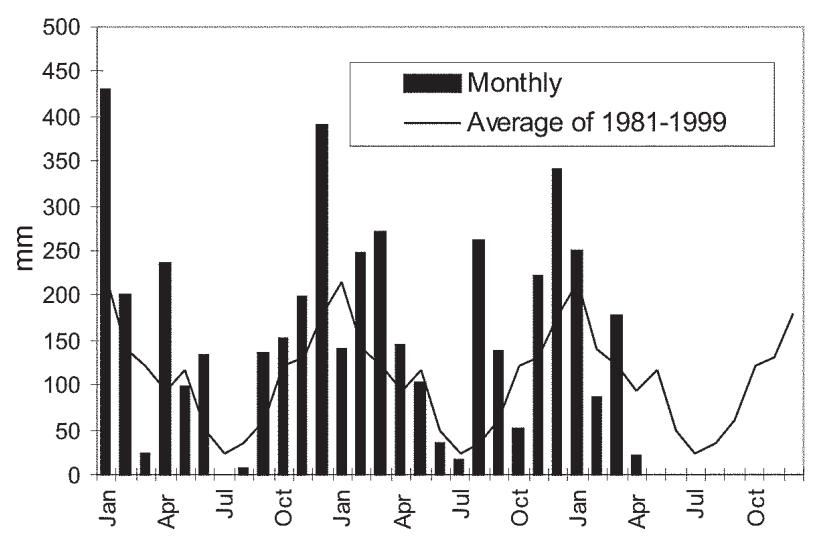

Fig. 3: monthly distribution of rainfall in Bonito county, from June 1997 to December 1999 and of the monthly average of the 19811999 period.

Pitangueiras farm, suprapylarian infection by flagellates was found in two. Some of these flagellates, though observed in the residuum of the slides submitted to testing with monoclonal antibodies, did not react to any available antibody, even to L1 that permits the identification of Leishmania sp. So the rate of natural infection by flagellates found by dissection was $0.22 \%$ for the Pitangueiras farm and $0.14 \%$ when all the environments sampled are taken into consideration.

The total number of phlebotomines captured by human attractiveness was $1194,95.6 \%$ in front of the mouth of the Pitangueiras cave (Table IX) and $4.4 \%$ in forest close to the C.C.I cave in the urban area of Bodoquena county (Table X). Five species, Lu. almerioi, Ma. oliveirai, N. whitmani, Mi. peresi, and Ps. punctigeniculata, were attracted. On the Pitangueiras farm, the males represented $0.96 \%$ of the total of specimens attracted while at C.C.I. their frequency was $11.3 \%$.

In both areas, Lu. almerioi predominated, on Pitangueiras farm with $96.6 \%$ and in Bodoquena city with $90.6 \%$. Its highest frequency occurred during the summer, when $46 \%$ and $37.5 \%$ of the specimens, respectively, were captured. Its intermediate frequency was observed during the spring, on Pitangueiras $31.7 \%$ and in Bodoquena
$31.3 \%$. Though less frequent, $L u$. almerioi was captured in considerable numbers in the seasons with very dry periods on Pitangueiras and in low numbers during the autumn in Bodoquena. The predominance in summer in relation to each of the other seasons was significant $(\mathrm{P} \leq$ 0.01) on Pitangueiras, but in Bodoquena, the significant difference $(\mathrm{P} \leq 0.05)$ occurred only in relation to the autumn.

The second most frequent species in both areas was N. whitmani, on Pitangueiras 3.2\% and in Bodoquena 3.8\%; as well as Ps. punctigeniculata at the latter. $N$. whitmani on Pitangueiras farm predominated in the winter, but without any significant difference (at the 5\% level) from the autumn. In Bodoquena only two specimens were captured in the winter.

On the Pitangueiras farm, of the 1093 females of $L u$. almerioi captured, $70.1 \%$ were dissected and only one of them was found to be infected by flagellates, observed only in the mid gut, giving a $0.13 \%$ rate for infection by flagellates. The identification of the flagellates was made by the monoclonal antibody (AcMc) test with the residues fixed on the slides. A weak reaction to AcMc B12, that usually reacts to Leishmania (Viannia), was detected. The culture was contaminated and the hamster did not develop any clinical manifestation of leishmaniasis during 6 months of observation. Of the 35 females of $N$. whitmani captured, 34 were dissected with negative results, just as for the two females of Mi. peresi dissected.

In the forest of Bodoquena city, $89.4 \%$ of the $47 \mathrm{fe}-$ males captured belonged to $\mathrm{Lu}$. almerioi. Practically all the females were dissected, but none of them was found to be infected by flagellates, precisely as occurred with the two females of N. whitmani and Ps. punctigeniculata and the one of Ma. oliveirai.

The nictemeral rhythm of females of Lu. almerioi captured on the Pitangueiras farm and also the local temperature and relative humidity (except for that of the autumn) are presented in Figs 4 and 5. The interval with highest frequencies varied throughout the seasons. The peaks occurred ever earlier as the rainy season approached. In all seasons the nocturnal activity began close to dusk, when a discreetly higher frequency occurred, though less high in the drier periods (autumn and winter), and extending until the morning peak, in such a way that when the nictemeral rhythm was obtained by the geometrical average (Fig. 5), two very clear peaks of activity could be identified, one close to dusk and another at dawn. About dawn, the frequencies were relatively high until 9:00 a.m. The minimal activity occurred between midday and 4:00 p.m.

For the Lu. almerioi population of Bodoquena city, activity is practically restricted to the nocturnal period, the greatest activity occurring between 5:00 and 11:00 p.m. with a single short peak from 7:00- 8:00 p.m.

Females of $N$. whitmani were also attracted by humans on the Pitangueiras farm between 6:00 p.m. and 2:00 a.m., with the Williams' average (females/h) by interval being: 18-19h (0.57), 19-20 h (1.14), 20-21 h (1.55), 21-22 h (0.86), 22-23 h (0.18), 23-0 h (0), 0-1 h (0.50), and 1-2 h $(0.18)$. 


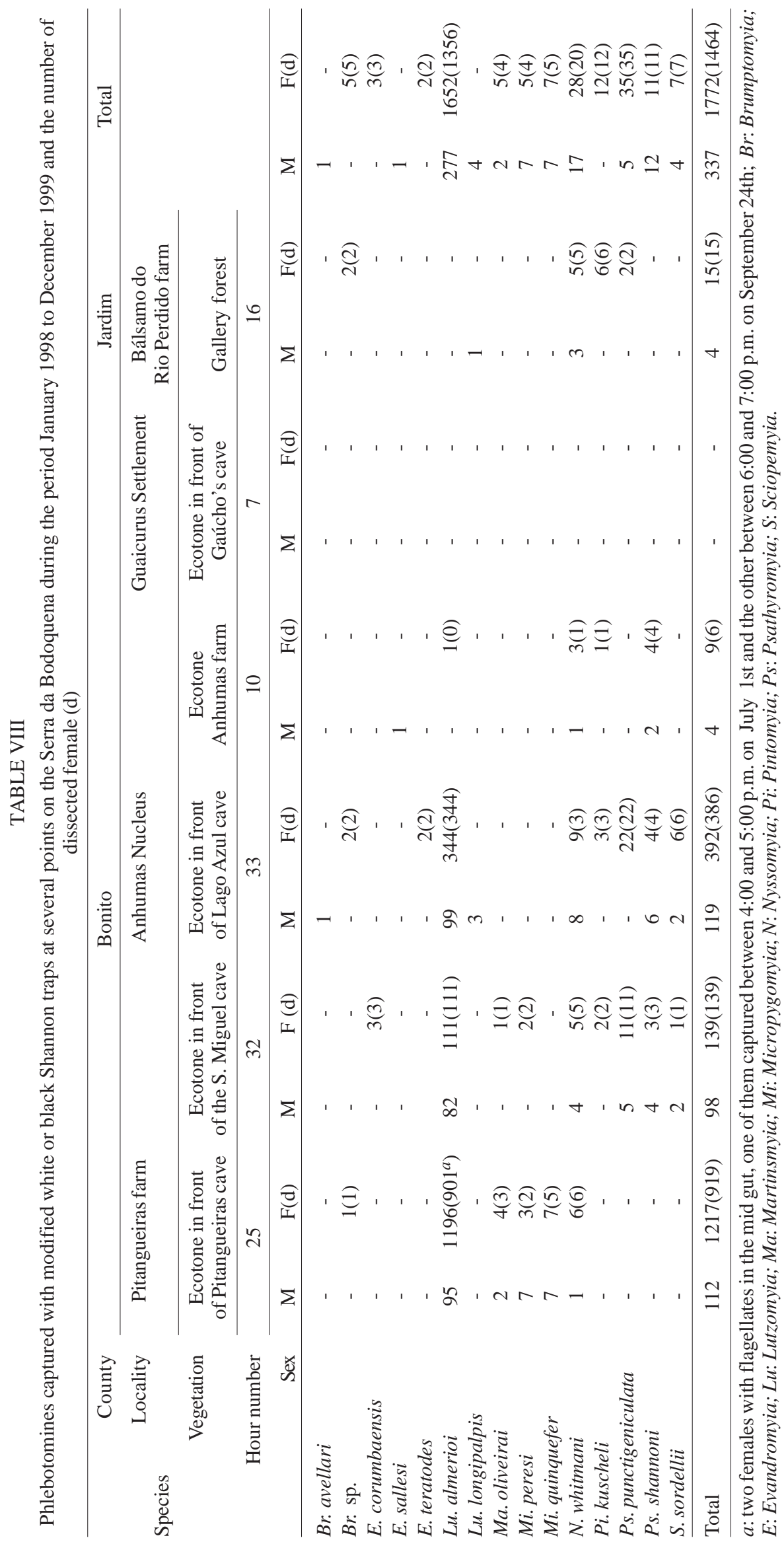




\section{TABLE IX}

Number of phlebotomines captured in $24 \mathrm{~h}$, on humans bait, once in each season, in forest, in front of the mouth of the Pitangueiras cave, Bonito county, and dissected females (d)

\begin{tabular}{|c|c|c|c|c|c|c|c|c|c|c|}
\hline \multirow{2}{*}{ Species } & \multicolumn{2}{|c|}{ Autumn } & \multicolumn{2}{|c|}{ Winter } & \multicolumn{2}{|c|}{ Spring } & \multicolumn{2}{|c|}{ Summer } & \multicolumn{2}{|c|}{ Total } \\
\hline & M & $F(d)$ & M & $F(d)$ & M & $F(d)$ & M & $F(d)$ & M & $F(d)$ \\
\hline Lu. almerioi & 2 & 134(119) & 2 & $107(95)$ & 4 & $346(255)^{a}$ & 1 & $506(307)$ & 9 & $1093(776)$ \\
\hline Ma. oliveirai & - & - & - & - & 1 & - & - & - & 1 & - \\
\hline Mi.peresi & - & - & - & - & - & $1(1)$ & - & $1(1)$ & - & $2(2)$ \\
\hline N. whitmani & 1 & $14(14)$ & - & 20(19) & - & - & - & $1(1)$ & 1 & $35(34)$ \\
\hline Total & 3 & $148(133)$ & 2 & 127(19) & 5 & $347(256)$ & 1 & $508(309)$ & 11 & $1130(812)$ \\
\hline
\end{tabular}

$a$ : one female with flagellates in the mid gut, captured between 6:00 a.m. and 7: 00 a.m; Lu: Lutzomyia; Ma: Martinsmyia; Mi: Micropygomyia; $N$ : Nyssomyia.

TABLE X

Number of phlebotomines captured in 24 h, on humans, once in each season, in forest close to the C.C.I. cave in the urban area of the Bodoquena county, and dissected females (d)

\begin{tabular}{|c|c|c|c|c|c|c|c|c|c|c|}
\hline \multirow{2}{*}{$\begin{array}{r}\text { Seasor } \\
\text { sex }\end{array}$} & \multicolumn{2}{|c|}{ Autumn } & \multicolumn{2}{|c|}{ Winter } & \multicolumn{2}{|c|}{ Spring } & \multicolumn{2}{|c|}{ Summer } & \multicolumn{2}{|c|}{ Total } \\
\hline & M & $F(d)$ & M & $\mathrm{F}(\mathrm{d})$ & M & $\mathrm{F}(\mathrm{d})$ & M & $\mathrm{F}(\mathrm{d})$ & M & $\mathrm{F}(\mathrm{d})$ \\
\hline Lu. almerioi & - & $3(2)$ & 1 & $11(11)$ & 5 & $10(9)$ & - & $18(18)$ & 6 & $42(40)$ \\
\hline Ma. oliveirai & - & $1(1)$ & - & - & - & - & - & - & - & $1(1)$ \\
\hline N. whitmani & - & - & - & $2(2)$ & - & - & - & - & - & $2(2)$ \\
\hline Ps. punctigeniculata & - & - & - & - & - & - & - & $2(2)$ & - & $2(2)$ \\
\hline Total & - & $4(3)$ & 1 & $13(13)$ & 5 & $10(9)$ & - & $20(20)$ & 6 & $47(45)$ \\
\hline
\end{tabular}

Lu: Lutzomyia; Ma: Martinsmyia; N: Nyssomyia; Ps: Psathysomyia.
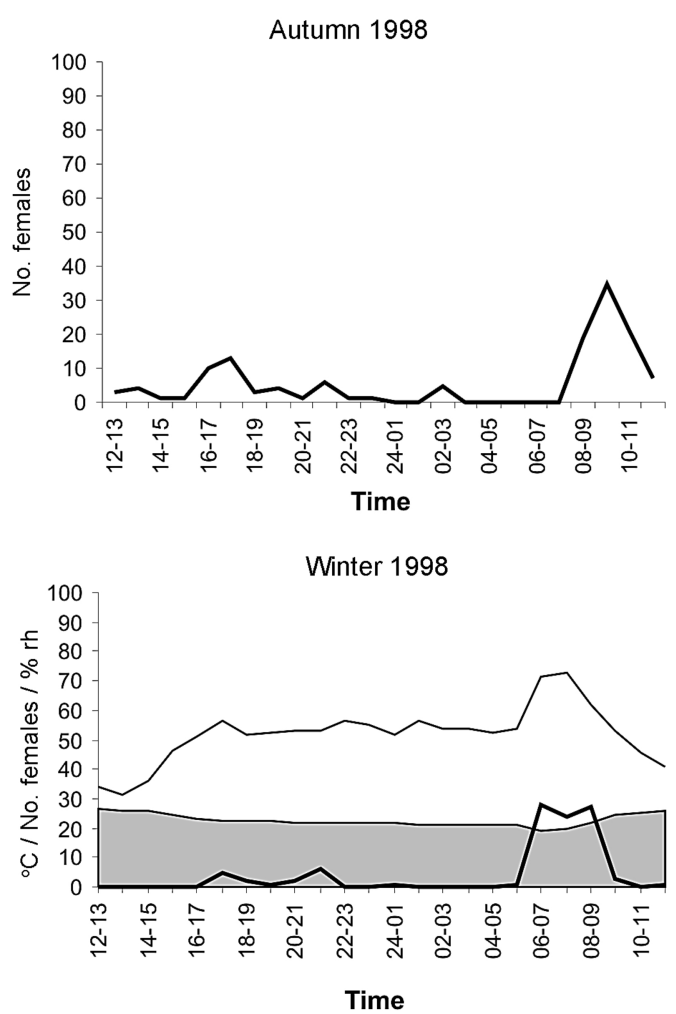

$$
\square{ }^{\circ} \mathrm{C}-\text { No. of females }-\% \text { rh }
$$
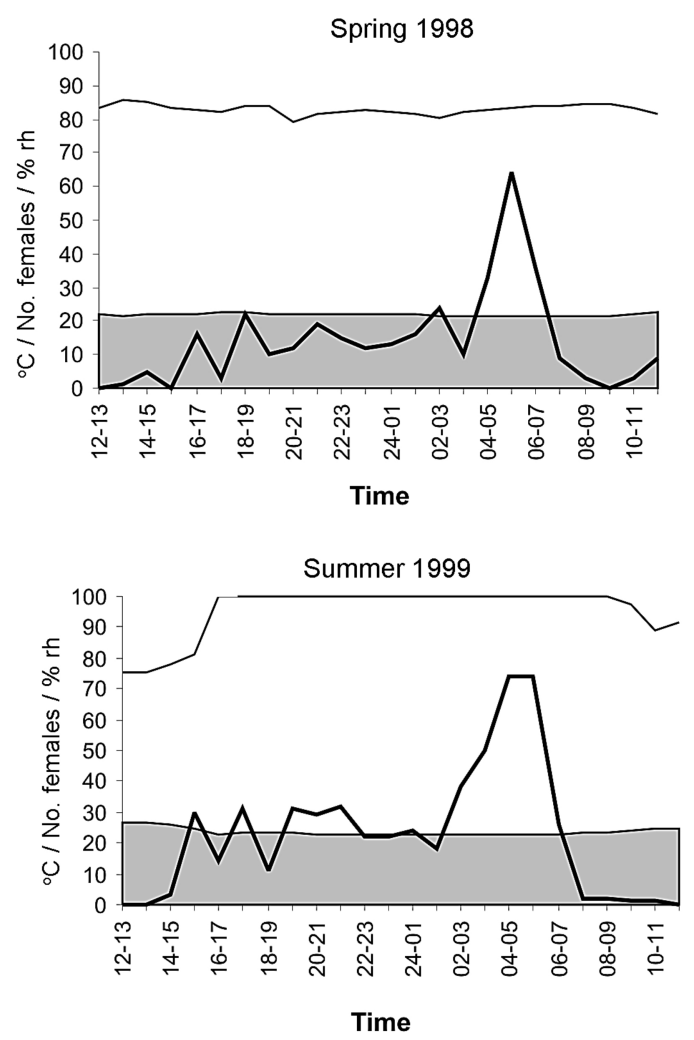

Time

Fig. 4: hourly frequency of Lutzomyia almerioi captured on humans, once a season in the period from June 1998 to February 1999 , by environmental temperature and relative humidity (except in autumn) in forest in front of the Pitangueiras cave mouth, Bonito county. 

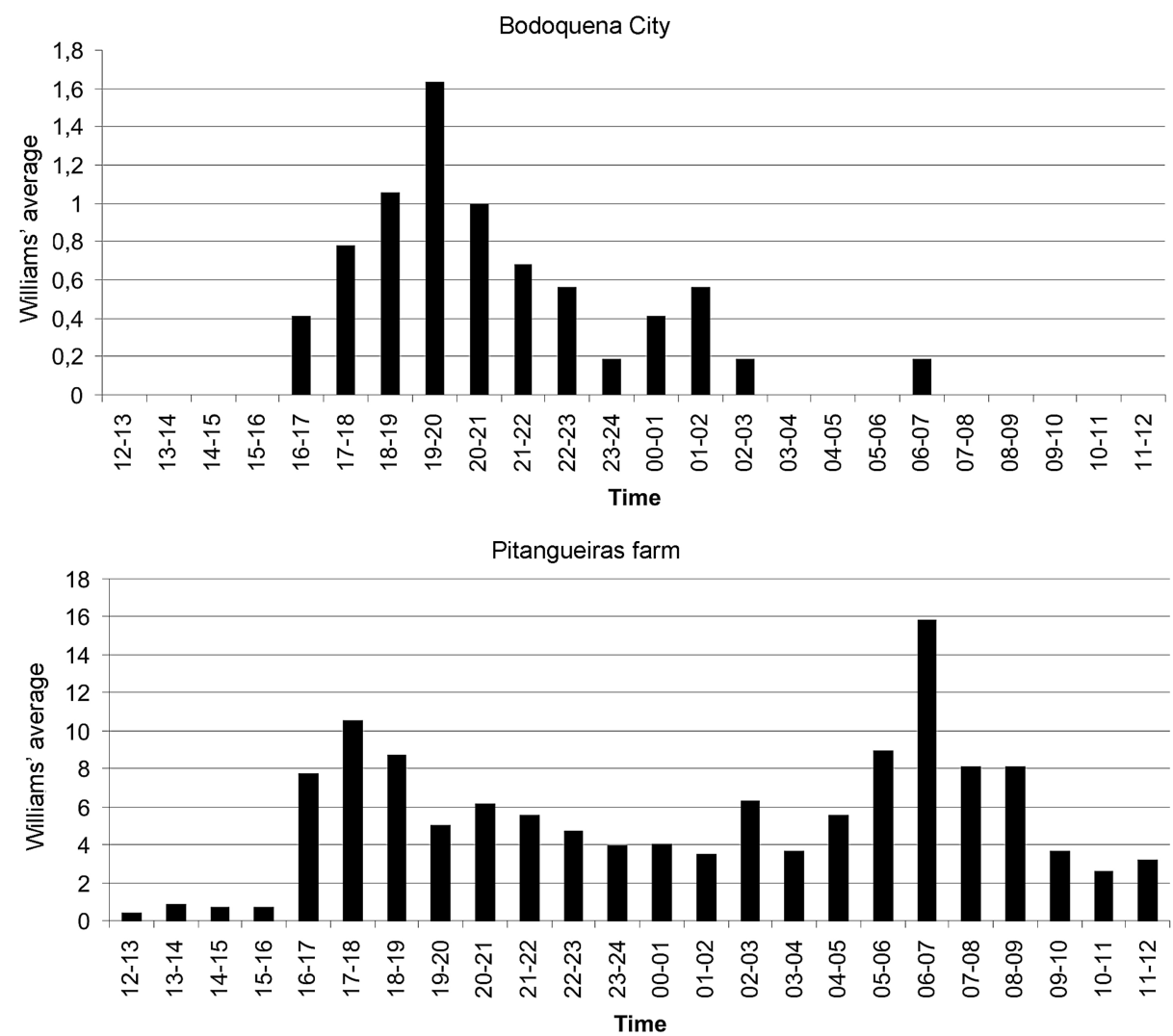

Fig. 5: average of the hourly frequency of Lutzomyia almerioi captured on humans once a season (March 1999 - December 1999) in forest beside the C.C.I. mouth cave, Bodoquena county and from June 1998 to February 1999 in front of the Pitangueiras cave mouth, Bonito county.

\section{DISCUSSION}

First, the results of the captures undertaken on the Guaicurus Settlement nucleus to describe the phlebotomines of a focus of canine visceral and human cutaneous leishmaniases have already been published (Galati et al. 2003b) and they have been included here for analysis within the wider context of the fauna of the Serra da Bodoquena as a whole.

The captures with automatic light traps, although yielding only meagre results, provided a fuller picture of a more extensive area over a period of one to two years at fortnightly intervals. So of the 23 species found on the Serra da Bodoquena, 22 were captured by this technique. The density obtained in this present study is not very different from that of the forested areas, using the same technique, as occurred on the Serra de Maracaju (3.6 insects/ trap) (Galati et al. 1996), the vegetation of which is closely similar to that of the Serra da Bodoquena and also to that of Campo Grande city (1.02 insects/trap) (Oliveira et al. 2003), both situated in the state of Mato Grosso do Sul (MS), as well as in the Atlantic vegetation domain of São Paulo, situated in the river basin of the Ribeira de Iguape (4.4 insects/trap) (Domingos et al. 1998). On the other hand, this density (i.e., of 2.4 insects/trap) is much lower than that observed in the Amazon forest in the northern region of Mato Grosso ( $c a$. 60.0 insects/trap in preserved and degraded areas) (Azevedo et al. 2002). It is also much inferior to that obtained in the 12 caves sampled on the Serra da Bodoquena (62.8 insects/trap) (Galati et al. 2003a).

The frequencies obtained by the Williams' average for each species on the western side (Table II) presented similar rankings to those obtained directly from the percentages (Table I). On the eastern side, there were differences (Tables III, IV): N. whitmani, Mi. quinquefer, and $E$. corumbaensis came higher in the ranking; the inverse occurring with $\mathrm{Lu}$. longipalpis and Ma. oliveirai, indicating for these two latter a lesser regularity in the captures.

On the western side, except for the seasonal deciduous sub-mountainous forest of the Bálsamo do Rio Perdido farm, the densities of phlebotomines in its forests were generally very low, just as in the caves on this same side (Galati et al. 2003a). However, in the forests on the Três Coxilhas farm a higher diversity was observed than that for Gaucho's cave. Whereas the diversity in Cezário's cave (Galati et al. 2003a) was greater than that in the forest of small farm 121, situated near this latter cave.

In the seasonal deciduous sub-mountainous forest the ecotope of the Bálsamo do Rio Perdido farm, where $N$. whitmani predominated (Table I), the significantly greater number $(\mathrm{P} \leq 0.001)$ of sand flies captured simultaneously as compared with those captured at other points (Table $\mathrm{V})$ is remarkable. At the Guaicurus nucleus, no statistically significant difference (at the 5\% level) was observed between the Salobrão farm and the small farms 121 and 
123 , nor between these latter; however, N. whitmani predominated in the former while on these latter, $\mathrm{Lu}$. almerioi and $L u$. longipalpis were practically equally dominant (Table I). On the other hand many more insects were captured $(\mathrm{P} \leq 0.001)$ at these three points than at the two points on the São Carlos and the Figueira farms. At one of the most northerly points only Lu. longipalpis was captured and at the southermost this species predominated, thus showing its wide distribution, although not predominant throughout all the areas. The Williams' averages (Table II) show E. corumbaensis, Lu. almerioi, Lu. longipalpis, and $N$. whitmani alternating in their predominance throughout the areas.

As regards the ecotone vegetation, no difference (at the $5 \%$ level) was found between canopy and ground level on the Três Coxilhas farm nor between these points and that on the São Carlos farm; however, at these three points a greater number of sand flies $(\mathrm{P} \leq 0.001)$ were captured than on the Figueira farm. All these areas are distant from any peridomiciliary environment, where domestic animal shelters may act as an attraction factor, and the difference between them may be attributed to the vegetation that is less dense on this latter.

At the Guaicurus nucleus in the canopy and at ground level of the Três Coxilhas farm ecotone a significant small number of sand flies $(\mathrm{P} \leq 0.05)$ were captured as compared with the three in the seasonal deciduous sub-mountainous forest (Salobrão farm and small farms 121 and 123) and also at one point in the gallery forest of the Salobrão farm. The proximity of the peridomicile to the seasonal deciduous sub-mountainous forest of the two small farms as well as of the ecotopes of the Salobrão farm would seem to explain these differences.

In the extreme areas sampled on the western side of the Serra da Bodoquena, on the São Carlos farm (north) and Figueira farm (south), where captures were undertaken from February 1999 to January 2000 and presented low returns, these latter were perhaps affected by the low rainfall during the greater part of this period since, in the other areas where captures were made during 1998 and 1999, a considerable reduction in the Williams' average for all the species was observed in this latter year, mainly on the eastern side (Figs 2, 3).

On the São Carlos farm, despite the small number of specimens captured, the area of ecotone presented a great number of species, hence its high diversity and evenness indexes and it was the only site at which E. lenti and Bi. flaviscutellata were captured. This latter species calls for special attention since it is the main vector of Leishmania (Le.) amazonensis, the aetiological agent of one of the most serious forms of the cutaneous leishmaniasis distributed throughout most of South America (Lainson \& Shaw 2005). The recent detection of this parasite in a focus of the disease in Bela Vista, a locality situated close to the southern limits of the Serra da Bodoquena (Fig. 1), where this sand fly has also been captured (Dorval et al. 2005), is noteworthy. Perhaps, had the present authors used Disney traps, as Dorval et al. (2005) did, the captures of this rodontophilic species would have been more numerous and their presence more widely spread. So these finds in north and south suggest that this species may be dispersed throughout the Serra da Bodoquena.

Neither of the two areas of gallery forest in the middle region of the western slopes showed any statistically significant difference as regards the total number of specimens captured simultaneously, though $L u$. almerioi was captured on the Salobrão farm but not on the Bálsamo do Rio Perdido farm. The other species: E. corumbaensis, $L u$. longipalpis, S. sordellii, and Pi. kuscheli were common to both areas, with the latter predominating in the former. The numerical predominance of $P i$. kuscheli over the other species occurred exclusively on the Salobrão farm; however, its geometrical average was not the highest, indicating no regularity in its captures. Of all the 12 caves sampled on the Serra da Bodoquena, only in Cezário's cave on the small farm 121 was this species (described from Bolivia) captured (Galati et al. 2003a).

On the eastern side, considering only those sites with one year of capture or more, the lowest averages were observed for canopy and ground on the Anhumas farm and the highest for canopy and ground level in the ecotone between forested savannah/seasonal deciduous submountainous forest on the Pitangueiras farm. In this latter area, in both canopy and at ground level, Lu. almerioi was the most frequent species, the averages being, respectively, 3.7 and 4.0 times higher than those for $M i$. quinquefer, the second in the ranking. In the ecotones close to the Lago Azul and S. Miguel caves, Lu. almerioi also predominated but its frequency in relation to the 2 nd in the ranking, was, respectively, 1.5 times higher than that of Lu. longipalpis and 2.8 times that of $E$. corumbaensis.

On the Pitangueiras farm and at the Anhumas nucleus the canopy and the ground level of areas with and without caves were sampled. In the former area the averages of canopy and ground level of the ecotone's forested areas close to the cave, were, respectively, 8.0 and 7.7 times higher than in the gallery forest. In the ecotones of the Anhumas nucleus, the averages for the canopy located close to the São Miguel cave and ground level close to the Lago Azul cave were, respectively, 3.1 and 4.5 times higher than those for the Anhumas farm, with no neighbouring cave.

The total of phlebotomines captured at ground level in the ecotone of the Pitangueiras farm was statistically significantly higher $(\mathrm{P} \leq 0.001)$ than those for the other points, including that of the canopy of this same ecotone; however, neither ground level nor canopy of the two other points sampled (gallery forest of the Pitangueiras farm and the ecotone of the Anhumas farm) presented any statistically significant differences for the respective areas (Table VI).

The captures in the canopy of the ecotones of the Pitangueiras farm and on the ground level close to that of the Lago Azul cave represented the second and third highest frequencies, respectively, and showed no statistically significant differences (at the $0.5 \%$ level) between them, though they were significantly different from that of the canopy on the São Miguel farm, the fourth in frequency.

The greatest frequencies in the total of phlebotomines captured both on the ground level and in the canopy in front of the Pitangueiras cave were certainly influenced 
by the proximity of this latter, which also presented the highest values found in the eleven caves sampled for at least one year, with $\mathrm{Lu}$. almerioi, which breeds mainly in caves, contributing $97.5 \%$ of the specimens captured there (Galati et al. 2003a). Though at a lower density than in the cave, this species contributed with $67 \%$ of the specimens captured at ground level and $60.1 \%$ of those in the canopy of this forested ecotone.

The ecotone surrounding the Lago Azul cave presented a higher frequency than that surrounding the São Miguel cave, whereas the opposite occurred inside the respective caves (Galati et al. 2003a). However, in the forest of São Miguel though giving a lower return than the two other areas with caves, i.e. Pitangueiras and Lago Azul, the captures made during the simultaneous period were greater and statistically more significant $(\mathrm{P} \leq 0.001)$ than those of the Anhumas farm (Table VI) with no cave; thus the caves seem to have influenced the phlebotomine density on this side of the Bodoquena ridge positively, mainly by virtue of the presence of $L u$. almerioi, which had the highest geometric averages in both forested areas.

The species E. sallesi, E. termitophila, E. teratodes, Ps. campograndensis, and Ps. shannoni were captured in the forest in front of the mouth of the Pitangueiras cave; $P i$. kuscheli in the forest surrounding the Lago Azul cave; E. termitophila and Ps. aragaoi in the forest on the Sao Miguel farm, but no specimen of the first three species or of Ps. aragaoi was captured inside these caves (Galati et al. 2003a).

The abundances of the species observed in the forests also differed from those found in the caves of the Serra da Bodoquena. Thus, in the caves, Lu. almerioi was the most abundant on both western and eastern sides (Galati et al. 2003a), whereas in the forests it was among the four most abundant species, though Lu. longipalpis and $N$. whitmani presented, respectively, the highest indexes in the forests on the western and eastern sites. When both sides were considered together this latter species was the most abundant, followed by $E$. corumbaensis, as in the caves. This latter was the predominant species in a cave situated in Corumbá city (MS) (Galati et al. 1997) but presented low abundance in Corguinho, located on the Serra de Maracaju (Galati et al. 1996).

The high abundance of $N$. whitmani (Table VII) has also been observed in other forested areas and in domestic animal shelters in the Northeastern, Midwestern, Southeastern, and Southern regions of Brazil as well as in Paraguay where this species has been considered the most important vector of cutaneous leishmaniasis (Pessôa \& Coutinho 1941, Vexenat et al. 1986, Hashiguchi et al. 1992, Queiroz et al. 1994, Galati et al. 1996, Luz et al. 2000, Teodoro et al. 1991, Souza et al. 2002, Dias-Lima et al. 2003, Leonardo $\&$ Rebêlo 2004). So the overwhelming predominance of this species in both seasonal deciduous sub-mountainous and gallery forests on the Bálsamo do Rio Perdido farm (Tables I, II) is perhaps due to the proximity of these two areas to the corral and pig pen which seem to influence the density of the species positively, since these shelters may act as artificial resting sites for the sand flies, or attract females to take their food from cattle and pigs as well as to find males for mating; the aspiration of $\mathrm{Lu}$. longipalpis males in a significantly greater number than that of the females on domestic animal baits of Guaicurus Settlement (Galati et al. 2003b) seems to corroborate this point of view.

Lu. longipalpis, the main vector of American visceral leishmaniasis, the most abundant in the captures with automatic light traps on the western side and the third most numerous when both sides are considered together, is a species whose high density is associated with degraded environments though it generally occurs in low densities in preserved seasonal deciduous sub-mountainous forest (Galati et al. 1996) or in savannah (Lainson \& Rangel 2003). So the absence of this species from the seasonal deciduous sub-mountainous forest of the Salobrão farm, though it was found in small numbers in the neighbouring gallery forest, domestic animal shelter and intradomicile (Galati et al. 2003b), may be attributed to the lesser degradation of the native vegetation surrounding the points sampled, due to the difficult access to this area. Conversely, on the Guaicurus Settlement, this species is well adapted to the peridomicile (Galati et al. 2003b). Further, the spread of the visceral leishmaniasis which is transmitted by this sand fly in large urban centres, mainly on the outskirts (Gontijo \& Melo 2004), seems to corroborate the hypothesis of its adaptation to degraded areas. Consequently, as the forests on the Bodoquena range generally present a high level of degradation as well as a predominance of ecotones intermediate between forested savannah and seasonal deciduous sub-mountainous vegetation with many rocky outcrops and loose stones which provide favorable conditions for the immature forms of this species, its abundance may have been considered predictable. Lu. longipalpis was captured only rarely by Shannon traps and was not attracted by humans at all in this present study. However, in an experiment on the attractiveness of domestic animals as well as of humans, it was captured only rarely on these latter as it greatly preferred the pig, followed by the horse, chicken, dog, and sheep, in that order (Galati et al. 2003b).

Ps. shannoni, although it was the fifth most abundant in the automatic light traps when both sides of the ridge are taken into consideration, was not attracted by humans, whereas in Corguinho (MS) its prevalence on this bait was of 2\% (Galati et al. 1996). It is one of the most widespread species in the forests of the Americas and has been described as anthropophilic in the Brazilian Northeast region (Vexenat et al. 1986, Queiroz et al. 1991), being the only anthropophilic species in Louisiana, US (Mascari 2005). This species has been found naturally infected by flagellates in several countries of Central and South America and there is evidence of its activity as a vector of the vesicular stomatitis virus, New Jersey serotype, in Georgia, US (Young \& Duncan 1994). Hence these differences in behaviour may indicate distinct taxa.

The Shannon diversity index $(\mathrm{H})$ for the western and eastern sides was, respectively, 1.95 and 1.63 and the evenness index (J) 0.72 and 0.54 (Tables I, III). The highest density found on the eastern side (2.4 times higher than that of the western side) and the high frequencies of $L u$. 
almerioi $(55.6 \%)$ certainly influenced, respectively, its smaller diversity and evenness indexes.

The lowest return rates for the forests of the Anhumas farm certainly contributed to the highest evenness index and the second highest diversity index, this latter being inferior only to that of the gallery forest (ground) of the Pitangueiras farm which also presented low density.

Distinct morphological patterns of rocks (Araújo et al. 1982) reflected in the predominant types of vegetation seem to be among the factors which account for the differences in the density and diversity observed between the western (15 species) and eastern sides ( 20 species). Thus, on the western side among the sampled areas, the seasonal deciduous sub-mountainous forest was predominant while on the eastern side the ecotones between this type of vegetation and forested savannah or low-lying seasonal deciduous forest/forested savannah were more numerous. In these ecotones, soils deeper than those of the seasonal deciduous sub-mountainous forests predominate, being covered with a higher vegetation which protects them from the sun's rays, and probably, present a greater quantity of organic matter that favours more numerous resting and/or breeding places for the sand fly species. Furthermore, the captures at 7 of the 11 points on the western side had only been undertaken during one year and at 5 of them only during a shorter period of drought, as may be observed in Fig. 3 .

Aspiration also added few specimens - 12 phlebotomines for a total of $102.5 \mathrm{~h}(0.12 \mathrm{insects} / \mathrm{h})$ - but resulted in the capture of a specimen of $\mathrm{Mg}$. bursifomis (= $M g$. bayti, according to Galati 2003); thus enlarging our knowledge of the phlebotomine fauna of the Serra da Bodoquena, and also in the capture of one specimen of Lu. almerioi, on the Bálsamo do Rio Perdido farm. Poor results were also obtained with this technique in some of the caves on the Serra da Bodoquena (Galati et al. 2003a).

The highest density of Lu. almerioi with human attractiveness occurred during spring and summer, i.e., in moister periods, just as was observed for the caves (Galati et al. 2003a). As regards the temperature and relative humidity, it was not possible to obtain these data for the autumn. For the other seasons, during the winter the temperature fell and the relative humidity rose during the early morning, being most marked between 5:00 and 8:00 a.m., coinciding with the activity peak of the females. On the other hand, when the sun rose, the temperature was not much different from that of the summer but the relative humidity was lower, probably because the leaves of the trees had fallen, permitting full incidence of the sun's rays, thus causing the disappearance of the females. During the spring the variations of temperature and relative humidity were not so clearly perceptible and in the summer this latter was high practically all the time, coming close to $100 \%$ during the best part of the period, the peak only occurring at dawn. Hence these data suggest that, apart from the temperature and the humidity, the intensity of the sunlight acts as a relevant microclimatic parameter for the displacement and haematophagic activity of the $L u$. almerioi females.

For $N$. whitmani, the only nocturnal haematophagic activity and predominance in the drier season (autumn and winter) were also observed in Corguinho, MS (Galati et al. 1996). The captures during autumn, winter, and spring occurred close to the first quarter of the lunar phase, and that of the summer, two days after the full moon, so with a higher intensity of moonlight than those in the other seasons. Thus, in these circumstances the higher frequencies in autumn and winter seem to be more dependent on some climatic factors than the intensity of the moonlight with which $N$. whitmani and $N$. intermedia populations from Rio de Janeiro presented significant positive correlation (Souza et al. 2005).

Though the use of human attractiveness is not normally ethically acceptable, the high degree of anthropophily and diurnal activity of one of the most frequent sand fly species in the region, which had not been described before the beginning of this project, was held to justify it for this specific project particularly because the human bait used were voluntary members of the author team.

Lu. almerioi, just as on humans, predominated absolutely in the captures with Shannon traps. Its infection rate among the females captured on humans $(0.13 \%)$ and in the Shannon traps $(0.22 \%)$, both on the Pitangueiras farm, was close to that observed in some foci of cutaneous leishmaniasis (Pessôa \& Coutinho 1941, Hashiguchi et al. 1992, Galati et al. 1996, Luz et al. 2000), but lower than that for visceral leishmaniasis (Santos et al. 1998).

Though in this study the identification of the flagellates was not possible, in a more recent study of the fauna of the Guaicurus Settlement, among the 1395 females (belonging to Lu. almerioi, Lu. longipalpis, and $N$. whitmani) dissected, the presence of flagellates was observed in three Lu. almerioi (Savani et al. 2005). These females were submitted to the polymerase chain reaction (PCR) and 15 pools were found to be positive for Leishmania DNA. The DNA of Leishmania infantum chagasi and that of Leishmania (Viannia) sp. were detected in Lu. almerioi and in Lu. longipalpis. In this latter sand fly, beyond these two parasites mentioned, Leishmania (Le.) amazonensis was also found (Savani et al. 2005).

In summary, the study undertaken in the forests of the Serra da Bodoquena, most of them surrounding caves which were also sampled, presented fauna very similar to those of these latter. However Bi. flaviscutellata, $M g$. bursiformis, and E. lenti were captured in the forested areas but not found in the caves, the opposite occurring for the species Brumptomyia galindoi and Sciopemyia sp. (Galati et al. 2003a). Thus the phlebotomine fauna for the ridge consists of 25 species.

Generally, in the forested areas of the Serra da Bodoquena the captures made with automatic light traps presented lower densities than those found in the caves and produced smaller returns, though a few traps close to the caves rendered a larger number of insects.

The difference between the diversity of the western (15 species) and eastern sides (20 species) may reflect the species' geomorphological distribution and also the fact that 7 of the 13 points on the western side were sampled only during one year while almost all of those on the eastern side were sampled during two complete years. Furthermore, the one-year sampling at 5 of the points occurred during a drought. 
Of all the species captured in the forests of the Serra da Bodoquena, four call for especial attention: $L u$. longipalpis, the main vector of Le. infantum chagasi, as one of the most abundant on both the western and eastern sides, in which natural infection by this parasite, as well as by Le. amazonensis and Le. (Viannia) sp., was recently identified in a focus of visceral canine and human cutaneous leishmaniasis on this ridge; Lu. almerioi, in which natural infection by Le. infantum chagasi and $L e .(V$.) sp. was also identified in this same focus (Savani et al. 2005); $N$. whitmani, the most abundant throughout the ridge, and the main vector of Le. braziliensis in other areas and Bi. flaviscutellata, a known vector of Le. amazonensis. However Lu. almerioi deserves special attention due to its high anthropophily and diurnal haematophagic activity, neither of which characteristics is found in Lu. longipalpis, and its high density and natural infection by flagellates. Thus its behaviour suggests its participation as vector of the agent of both visceral and cutaneous leishmaniases on the Serra da Bodoquena. However, it is necessary to demonstrate its vectorial competence by experimental transmission. Further, $L u$. almerioi, with one of the highest densities, mainly on the eastern side, may also cause bother to inhabitants and people who visit the area, due to its anthropophily, painful bite and diurnal activity.

\section{ACKNOWLEDGEMENTS}

To various of the inhabitants of the Serra da Bodoquena: Mrs Adélia Gonçalves de Souza, Mrs Zélia Maria Araújo, and Mr Sérgio Ferreira Gonzales, José Barbosa de Araújo, Denivaldo Torrecilha Pereira, Edir Rosa Ribeiro, and Ceciliano Pereira, for their collaboration in the captures; Dr João Carlos Meirelles, owner of the Pitangueiras farm, and Mr João Alberto Baptistella, owner of the São Bento farm, for having provided us with the necessary facilities during field research and Mrs Edna Ishikawa, Instituto Evandro Chagas, for the identification of the flagellates.

\section{REFERENCES}

Alvarenga SM, Brasil AE, Del' Arco DM 1982. Folha SF-21 Campo Grande, 2 - Geomorfologia. Projeto RADAM BRASIL, Rio de Janeiro, 28: 125-184.

Araújo HJT, Santos-Neto A, Trindade CAH, Pinto JCA, Montalvão RMG, Dourado TDC, Palmeira RCB, Tassinari CCG 1982. Folha SF-21 - Campo Grande, 1- Geologia. Projeto RADAMBRASIL, Rio de Janeiro, 28: 9-124.

Azevedo A, Souza NA, Meneses CRV, Costa WA, Costa SM, Lima JB, Rangel EF 2002. Ecology of sand flies (Diptera: Psychodidae: Phlebotominae) in north of the State of Mato Grosso, Brazil. Mem Inst Oswaldo Cruz 97: 459-464.

Boggiani PC, Coimbra AM 1995. Quaternary limestone of the pantanal area, Brazil. An Acad Bras Ciênc 67: 343-349.

Dias-Lima AG, Guedes MLS, Sherlock IA 2003. Horizontal stratification of sandfly (Diptera: Psychodidae) in a transitional vegetation between caatinga and tropical rain forest, state of Bahia, Brazil. Mem Inst Oswaldo Cruz 98: 733737.

Domingos MF, Carrieri-Bruno GC, Ciaravolo RMC, Galati EAB, Wanderley DMV, Corrêa FMA 1998. Leishmaniose tegumentar americana: flebotomíneos de área de transmissão, no município de Pedro de Toledo, região sul do Estado de São Paulo, Brasil. Rev Soc Bras Med Trop 31: 425-432.

Dorval MEC, Oshiro ET, Cristaldo G, Rocha HC, Peixoto T, Alves MA, Oliveira AG, Galati EAB, Brazil RP, Cunha RV 2005. The sandfly fauna (Diptera: Psychodidae: Phlebotominae) of an area of cutaneous leishmaniasis in municipality of Bela Vista, Mato Grosso do Sul state, Brazil. Proceedings of ISOPS V. Arch Inst Pasteur Tunis 82: 107.

Forattini OP 1973. Entomologia Médica. Phlebotominae. Leishmanioses. Bartonelose, Edgard Blücher Ltda, São Paulo, $658 \mathrm{pp}$.

Furtado PP, Guimarães JG, Fonzar BC 1982. Folha SF-21 Campo Grande, 4 - Vegetação. Projeto RADAMBRASIL, Rio de Janeiro, 28: 281-336.

Galati EAB 2003. Classificação de Phlebotominae. In EF Rangel, R Lainson, Flebotomíneos do Brasil, Fiocruz, Rio de Janeiro, p. 23-51.

Galati EAB, Nunes VLB, Dorval MEC, Oshiro ET, Cristaldo G, Espínola MA, Rocha HC, Garcia WB 1996. Estudo dos flebotomíneos (Diptera, Psychodidae), em área de leishmaniose tegumentar, no Estado de Mato Grosso do Sul, Brasil. Rev Saú Púb 30: 115-128.

Galati, EAB, Nunes VLB, Rego-Jr FA, Oshiro ET, Rodrigues M 1997. Estudo de flebotomíneos (Diptera, Psychodidae) em foco de leishmaniose visceral no Estado de Mato Grosso do Sul, Brasil. Rev Saú Púb 31: 378-390.

Galati EAB, Nunes VLB, Dorval MEC, Cristaldo G, Rocha HC, Gonçalves-Andrade RM, Naufel G 2001. Attractiveness of black Shannon trap for phlebotomines. Mem Inst Oswaldo Cruz 96: 641-647.

Galati EAB, Nunes VLB, Boggiani PC, Dorval MEC, Cristaldo G, Rocha HC, Oshiro ET, Gonçalves-Andrade RM, Naufel G 2003a. Phlebotomine (Diptera, Psychodidae) in caves of the Serra da Bodoquena, Mato Grosso do Sul state, Brazil. Rev Bras Entomol 47: 283-296.

Galati EAB, Nunes VLB, Cristaldo G, Rocha HC 2003b. Aspectos do comportamento da fauna flebotomínea (Diptera:Psychodidae) em foco de leishmaniose visceral e tegumentar na Serra da Bodoquena e área adjacente, Estado de Mato Grosso do Sul, Brasil. Rev Pat Trop 32: 235-261.

Gnaspini Netto P, Trajano E, Sánchez LE 1994. Província espelológica da Serra da Bodoquena, MS: exploração, topografia e biologia. Espelo-Tema 17: 19-44.

Gontijo CMF, Melo MN 2004. Leishmaniose visceral no Brasil: quadro atual, desafios e perspectivas. Rev Bras Epid 7: 338-349.

Haddow AJ 1960. Studies on the biting-habits and medical importance of East African mosquitos in the genus Aedes. I. Subgenera Aedimorphus, Banksinella and Nunnius. Bull Entomol Res 50: 759-779.

Hashiguchi Y, Chiller T, Inchausti A, De Arias A, Kawabata M, Alexander JB 1992. Phlebotomine sandfly species in Paraguay and their infection with Leishmania. Ann Trop Med Parasitol 86: 175-180.

Hayek LAC, Buzas MA 1997. Surveying Natural Populations, Columbia University Press, New York, p. 347-389.

Lainson R, Shaw JJ 2005. New World Leishmaniasis. In FEG 
Cox, JP Kreier, D Wakelin (eds), Microbiology and Microbial Infections, Parasitology, Topley \& Wilson's, Arnold, Sydney, Auckland, p. 313-349.

Lainson R, Rangel EF 2003. Lutzomyia longipalpis e a ecoepidemiologia da leishmaniose visceral americana (LVA) no Brasil. In EF Rangel, R Lainson, Flebotomíneos do Brasil, Fiocruz, Rio de Janeiro, p. 311-336.

Leonardo FS, Rebêlo JMM 2004. A periurbanização de Lutzomyia whitmani em área de foco de leishmaniose cutânea, no Estado do Maranhão, Brasil. Rev Soc Bras Med Trop 37: 282-284.

Luz E, Membrive N, Castro EA, Dereure J, Pratlong F, Dedet A, Pandey A, Thomaz-Soccol V 2000. Lutzomyia whitmani (Diptera, Psychodidae) as vector of Leishmania (Viannia) braziliensis in Paraná state, southern Brazil. Ann Trop Med Parasit 94: 623-631.

Mascari TM. 2005. Habitat associations of Lutzomyia shannoni (Dyar) (Diptera: Psychodidae) in urban Baton Rouge, Louisiana, USA. Proceedings of ISOPS V, Arch Inst Pasteur Tunis 82: 23.

Natal D, Marucci D, Reis IM, Galati EAB 1991. Modificação da armadilha CDC com testes para coletas de flebotomíneos (Diptera). Rev Bras Entomol 35: 697-700.

Nunes VLB, Galati EAB, Nunes DB, Zinezzi RO, Savani ESMM, Isshikawa E, Camargo MCGO, D’Ária SRN, Cristaldo G, Rocha HC 2001. Ocorrência de leishmaniose visceral canina em assentamento agrícola no Estado de Mato Grosso do Sul, Brasil. Rev Soc Bras Med Trop 34: 299-300.

Oliveira AG, Andrade-Filho JD, Falcão AL, Brazil RP 2003. Estudo de flebotomíneos (Diptera, Psychodidae, Phlebotominae) na zona urbana da cidade de Campo Grande, Mato Grosso do Sul, Brasil. 1999-2000. Cad Saú Púb 19: 993-944.

Pessôa SB, Coutinho JO 1941. Infecção natural e experimental dos flebótomos pela Leishmania brasiliensis, no Estado de São Paulo. Hospital 20: 25-35.

Queiroz RG, Vasconcelos IA, Vasconcelos AW, Pessoa FA, Souza RN, David JR 1994. Cutaneous leishmaniasis in Ceará state in northern Brazil: incrimination of Lutzomyia whitmani (Diptera: Psychodidae) as vector of Leishmania braziliensis in Baturité municipality. Amer J Trop Med Hyg 50: 693698.
Ratter JA, Bridgewater S, Ribeiro JF 2001. Espécies lenhosas da fitofisionomia cerrado sentido amplo em 170 localidades do bioma cerrado. B Herb Ezechias Paulo Heringer 7: 5112 .

Roberts DR, Hsi BP 1979. An index of species abundance for use with mosquito survillance data. Environ Entomol 8: $1007-1013$

Santos SO, Arias JA, Ribeiro AA, Hoffmann MP, Freitas TA, Malacco MAF 1998. Incrimination of Lutzomyia cruzi as a vector of American visceral leishmaniasis. Med Vet Entomol 12: 315-317.

Savani ESMM, Galati EAB, Nunes VLB, Castilho TM, Camargo MCO, D'Ária SRN, Floeter-Winter LM 2005. Natural infection in sand fly vectors in cutaneous and visceral leishmaniasis foci in Mato Grosso do Sul state, Brazil. Proceedings of ISOPS V, Arch Inst Pasteur Tunis 82: 48-49.

Souza NA, Andrade-Coelho CA, Vilela ML, Peixoto AA, Rangel EF 2002. Seasonality of Lutzomyia intermedia and Lutzomyia whitmani (Diptera: Psychodidae: Phlebotominae), occurring sympatrically in area of cutaneous leishmaniasis in the state of Rio de Janeiro, Brazil. Mem Inst Oswaldo Cruz 97: 759-765.

Souza NA, Andrade-Coelho CA, Silva VC, Peixoto AA, Rangel EF. 2005. Moonlight and blood-feeding behaviour of Lutzomyia intermedia and Lutzomyia whitmani (Diptera: Psychodidae: Phlebotominae), vectors of American cutaneous leishmaniasis in Brazil. Mem Inst Oswaldo Cruz 100: 39-42.

Teodoro U, La Salvia-Filho N, Lima EM, Misuta NM, Verginassi TG, Ferreira MEMC 1991. Leishmaniose tegumentar americana. Flebotomíneos de área de transmissão no norte do Paraná, Brasil. Rev Saú Púb 25: 129-133.

Veloso HPA, Rangel Filho LR, Lima JCA 1991. Classificação da Vegetação Brasileira, Adaptada a um Sistema Universal, IBGE, Rio de Janeiro, 124 pp.

Vexenat JA, Barreto AC, Cuba CC, Marsden PD 1986. Características epidemiológicas da leishmaniose tegumentar americana em uma região endêmica do estado da Bahia III. Fauna flebotomínica. Mem Inst Oswaldo Cruz 81: 293-301.

Young DG, Duncan MA 1994. Guide to the identification and geographic distribution of Lutzomyia sand flies in Mexico, the West Indies, Central and South America (Diptera: Psychodidae). Mem Amer Entomol Inst 54: 1-881. 